\title{
26. ICHTHYOLITH STRONTIUM ISOTOPIC STRATIGRAPHY OF DEEP-SEA CLAYS: SITES 885 AND 886 (NORTH PACIFIC TRANSECT) ${ }^{1}$
}

\author{
B. Lynn Ingram ${ }^{2}$
}

\begin{abstract}
Ichthyoliths (fish remains) from North Pacific pelagic clay recovered at Ocean Drilling Program (ODP) Sites 885 and 886 were dated with high-precision strontium isotopic ratio measurements $\left({ }^{87} \mathrm{Sr} /{ }^{86} \mathrm{Sr}\right)$. These data provide age control and allow determination of linear sedimentation rates within the clay units, which are barren of other fossils.

Strontium isotopic data of fish teeth from the base of the clay unit (Unit III) from Holes 885A and 886C indicate deposition of the clay began in the Late Cretaceous (between 76.5 and $79.0 \mathrm{Ma}$ ). The ${ }^{87} \mathrm{Sr} /{ }^{86} \mathrm{Sr}$ ratios of fish teeth from the top of Unit III indicate an age of late Miocene (6.1 Ma), and marks the transition from slowly accumulating pelagic clay (Unit II) to more rapidly accumulating diatom ooze. This result is consistent with radiolarian and diatom biostratigraphy.

In Hole $886 \mathrm{C}$, ichthyolith identifications and ${ }^{87} \mathrm{Sr}{ }^{86} \mathrm{Sr}$ ratio measurements and the presence of spherules from an interval with an anomalously high iridium concentration (top of Core $8 \mathrm{H}$ ) confirm an age of the Cretaceous/Tertiary boundary, Untreated ichthyolith samples below this level had anomalously high ${ }^{87} \mathrm{Sr} /{ }^{86} \mathrm{Sr}$ ratios. After leaching with acetic acid to remove adhered $\mathrm{Fe}-\mathrm{Mn}$ oxides and clays, the ${ }^{87} \mathrm{Sr}{ }^{86} \mathrm{Sr}$ ratio of the ichthyoliths was much lower, showing deposition during the Late Cretaceous beginning at $76.5 \mathrm{Ma}$, which is consistent with the basement age of $80 \mathrm{Ma}$ (Keller, 1993).

The variation of the average sedimentation rate of the pelagic clay unit at Hole $886 \mathrm{C}$ from $0.24 \mathrm{~m} / \mathrm{m}$.y. in Unit IIIa to an increased rate of $0.51 \mathrm{~m} / \mathrm{m}$.y. in Subunit IIIb, perhaps resulted from increased hydrothermal influx (Dickens and Owen, this volume). These rates are consistent with previously determined sedimentation rates in North Pacific pelagic clays.
\end{abstract}

\section{INTRODUCTION}

Pelagic clays recovered at ODP Sites 885 and 886 in the North $\mathrm{Pa}-$ cific (Fig. 1) consist of terrigenous, hydrothermal, and hydrogenous (authigenic) minerals, and contain abundant information about the history of ocean chemistry, eolian, and terrigenous sedimentation in the deep sea (Shipboard Scientific Party, 1993). For example, particle size, composition, and mass accumulation rate of the eolian component serve as a proxy indicator of atmospheric circulation (e.g., Leinen and Heath, 1981; Rea et al., 1985). However, accurate age control of the sediments is critical for understanding the processes influencing the mineralogical and compositional variations recorded in the deposits, and for relating these to other paleoceanographic and paleoclimatic events.

Dating of the deep-sea sediments by conventional biostratigraphic methods is precluded in these sequences because the sediments are barren of siliceous and calcareous fossils, owing to deposition at abyssal depth. The only biogenic components contained within the sediments are ichthyoliths, or microscopic teeth and other skeletal and dermal fragments of fishes. The development of ichthyolith biostratigraphy has provided the chronostratigraphy for many central North Pacific pelagic clay sequences, such as GPC-3 and Deep Sea Drilling Project (DSDP) sites (Doyle and Riedel, 1979; Gottfried et al., 1984a, 1984b). The stratigraphic age ranges for the ichthyoliths have been determined from their association with other samples dated with calcareous nannofossils, foraminifers, and radiolarians (Doyle and Riedel, 1979; Gottfried et al., 1984a).

'Rea, D.K., Basov, I.A., Scholl, D.W., and Allan, J.F. (Eds.), 1995. Proc. ODP, Sci. Results, 145: College Station, TX (Ocean Drilling Program).

${ }^{2}$ Department of Geology and Geophysics, University of California, Berkeley, CA 94720 , U.S.A.
Because of the relatively large age uncertainties associated with ichthyolith biostratigraphy, other methods for determining relative ages of pelagic clays have been developed. One example is the hydrogenous cobalt accumulation rate, which assumes a constant flux of hydrogenous cobalt and is inversely proportional to the sedimentation rate (Kyte et al., 1993). A comparison of Co accumulation rates and ichthyolith biostratigraphy in GPC-3 has revealed substantial discrepancies between these two dating methods, particularly during periods of very low sedimentation rate (Kyte et al., 1993). Another dating method is the accumulation rate of ${ }^{10} \mathrm{Be}$, which assumes a constant burial rate of cosmogenic Be (Mangini et al., 1984), but ${ }^{10} \mathrm{Be}$ ages have also been shown to deviate from ichthyolith biostratigraphic ages in GPC-3 during much of the Miocene and Pliocene.

Previous studies have demonstrated that primary fish tooth apatite accurately records the strontium isotopic composition of the seawater in which the fish lived (Staudigel et al., 1985; Ingram, 1992; Ingram et al., 1994). Refinements of the Cenozoic and Cretaceous seawater strontium isotopic evolution curve (e.g., Swinburne et al., in press; DePaolo and Ingram, 1985; Hess et al., 1986; Capo and DePaolo, 1990), as well as improvements in sample preparation and high-precision isotopic measurement techniques, have improved high-resolution dating of small amounts $(<200 \mu \mathrm{g})$ of microscopic fish teeth. Dating of the fish tooth apatite is accomplished by comparison of ${ }^{87} \mathrm{Sr} /{ }^{86} \mathrm{Sr}$ ratios measured in the teeth with the strontium seawater evolution curve for the Cretaceous and Cenozoic. This assumes that the measured ${ }^{87} \mathrm{Sr} /{ }^{86} \mathrm{Sr}$ ratio has not been diagenetically altered since the time of its burial.

In this study, pelagic clay sediments are dated from ODP Sites 885 and 886 with ${ }^{87} \mathrm{Sr} /{ }^{86} \mathrm{Sr}$ ratio measurements of ichthyolith apatite extracted from the sediments and the linear sedimentation rates of the pelagic clays are determined. Ichthyoliths are also identified from the period from the Late Cretaceous to late Eocene, when the ${ }^{87} \mathrm{Sr} /{ }^{86} \mathrm{Sr}$ ratio in seawater remained fairly constant. Although not a primary fo- 


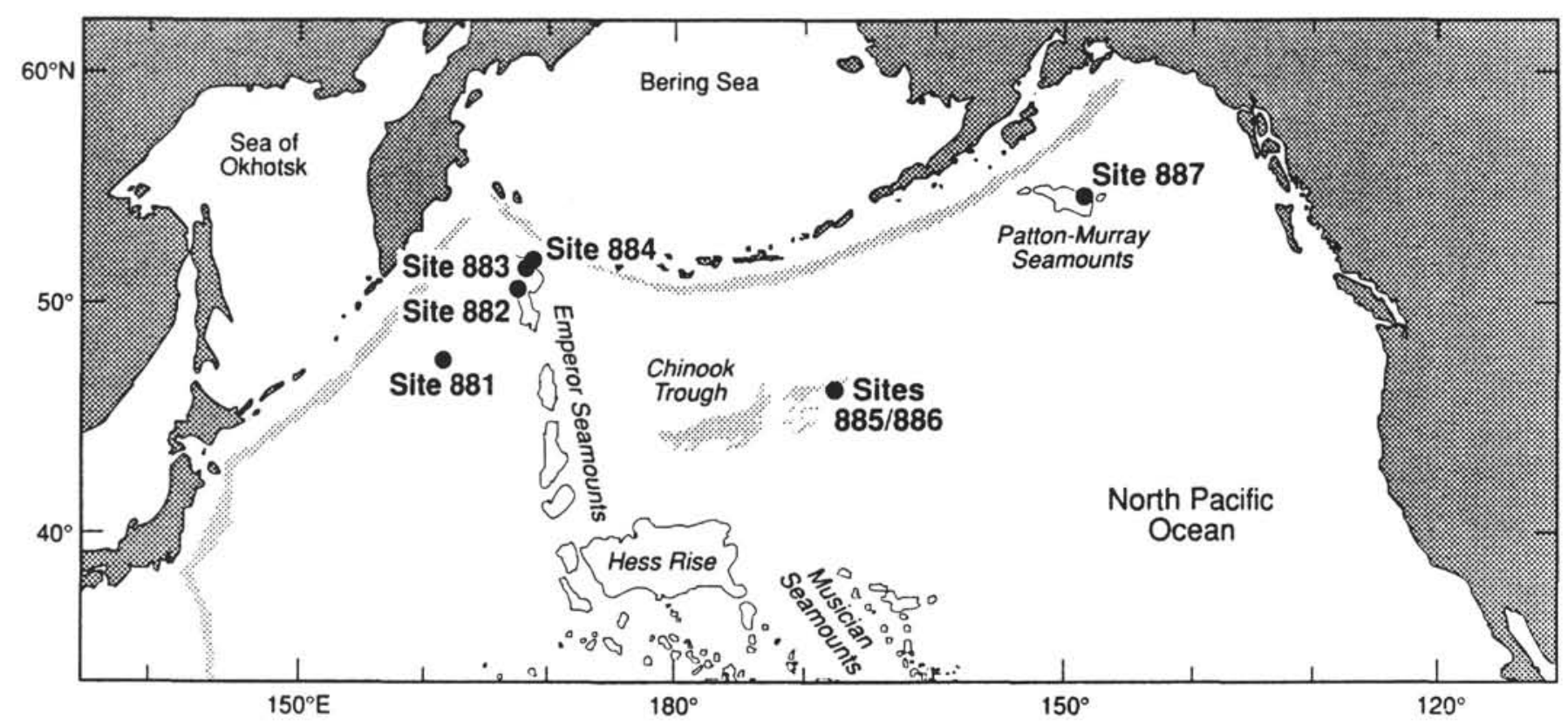

Figure 1. Location map showing Sites 885 and 886 in the North Pacific Ocean.

cus this study, some types of distinctive ichthyoliths were identified and most of the representative types of ichthyoliths were photographed by scanning electron microscope (SEM).

\section{METHODS \\ Strontium Isotope Stratigraphy}

The isotopic composition of $\mathrm{Sr}$ in the oceans reflects the isotopic composition and relative proportions of Sr entering the ocean (Palmer and Edmond, 1989). The globally averaged riverine $\mathrm{Sr}$ isotopic composition is relatively high $\left({ }^{87} \mathrm{Sr} /{ }^{86} \mathrm{Sr}\right.$ ratio $\left.=0.710\right)$, whereas seawater $\mathrm{Sr}$ derived from ocean-floor rocks at mid-ocean ridges is relatively low (average ${ }^{87} \mathrm{Sr}{ }^{86} \mathrm{Sr}$ ratio $=0.703$ ). $T$ The ${ }^{87} \mathrm{Sr} /{ }^{86} \mathrm{Sr}$ ratio in seawater is generally highest during periods of mountain building and continental collision, owing to the large flux of continentally derived material (Richter et al., 1992). Conversely, the ${ }^{87} \mathrm{Sr} /{ }^{86} \mathrm{Sr}$ ratio in seawater is lowest in seawater during periods of continental break-up and rapid seafloor spreading.

Measurements of the ${ }^{87} \mathrm{Sr} /{ }^{86} \mathrm{Sr}$ ratio of calcium-bearing marine precipitates show that the ${ }^{87} \mathrm{Sr} / 86 \mathrm{Sr}$ ratio in seawater has fluctuated over the past 600 m.y. between the limits of 0.7068 and 0.7092 (Burke et al., 1985). Because the residence time of $\mathrm{Sr}$ in seawater (3 to $4 \mathrm{~m} . \mathrm{y}$.) is much longer than the mixing time of the oceans ( 1000 years), the ${ }^{87} \mathrm{Sr} /{ }^{86} \mathrm{Sr}$ ratio in seawater is homogeneous in the oceans at any given time. Thus, the ${ }^{87} \mathrm{Sr} /{ }^{86} \mathrm{Sr}$ ratio of unaltered fish-tooth apatite, and other marine precipitates, can be dated by comparison with the seawater reference curve.

\section{Strontium Isotopic Reference Curve}

The $\mathrm{Sr}$ isotopic reference curve used in this study is composed of several hundred ${ }^{87} \mathrm{Sr} /{ }^{86} \mathrm{Sr}$ ratio measurements made over the past 10 $\mathrm{yr}$ for carbonate and phosphate samples spanning the past $80 \mathrm{Ma}$ (Fig. 2 ). The samples used for the reference curve include separated foraminiferal samples from DSDP Sites 575 and 590B (DePaolo, 1986; DePaolo and Finger, 1991; Capo and DePaolo, 1990; Hess et al., 1986), macrofossils from European type localities (DePaolo and Ingram, 1985), and Upper Cretaceous to Paleocene bulk carbonates and iichthyoliths separated from pelagic marls collected from the Um-

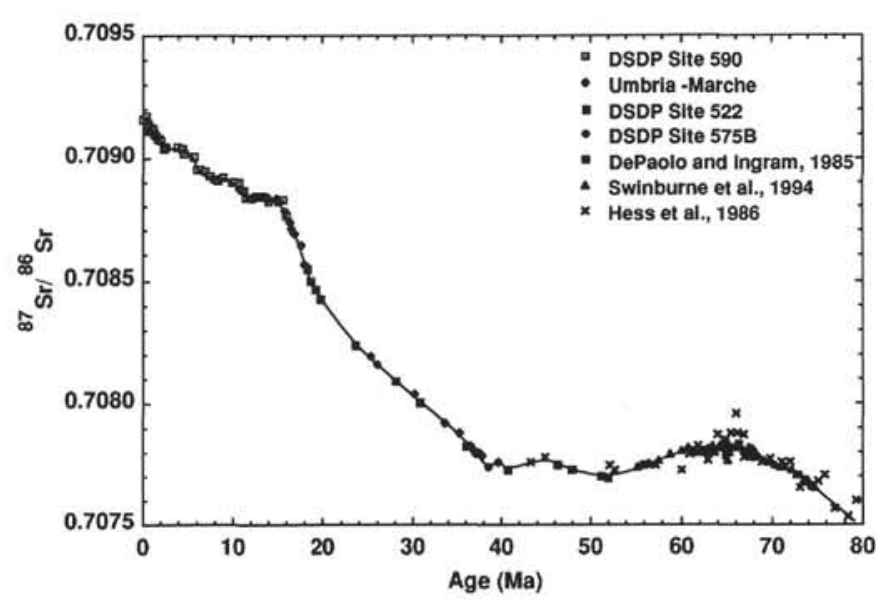

Figure 2. Strontium isotopic reference curve for $80 \mathrm{Ma}$ to the present.

bria-Marche region of the northern Apennines (Swinburne et al., in press). During periods in which the ${ }^{87} \mathrm{Sr} /{ }^{86} \mathrm{Sr}$ ratio of seawater is increasing rapidly, such as from the late Eocene through the present (when it increases from 0.70775 to 0.709189 ), stratigraphic resolution is best. However, during much of the Paleocene and Eocene, the ${ }^{87} \mathrm{Sr} /{ }^{86} \mathrm{Sr}$ of seawater remains relatively constant, fluctuating between 0.70770 and 0.70785 . During the Late Cretaceous, the seawater ${ }^{87} \mathrm{Sr} /$ ${ }^{86} \mathrm{Sr}$ ratio increased from about 0.70750 at $80 \mathrm{Ma}$ to between 0.70782 and 0.70795 at the Cretaceous/Tertiary boundary (Swinburne et al., in press; Hess et al., 1986). Deep-sea foraminifers from the Cretaceous/Tertiary boundary have ${ }^{87} \mathrm{Sr} /{ }^{86} \mathrm{Sr}$ ratios consistently higher than pelagic carbonates from shallower marine settings, such as that represented by the Umbrian-Marche region of the Apennines (Italy) by 0.00005 to 0.0001 (Swinburne et al., in press; Fig. 2).

\section{Sample Preparation}

Samples used in this study were all taken on board Leg 145: one $10 \mathrm{~cm}^{3}$ sample was taken per core section at Sites 885 and 886 within 
the pelagic clay units. In addition, core-catcher samples were sieved and the ichthyoliths separated on board by D. Pak.

To separate the microscopic ichthyoliths from clay matrix, the sediment samples were soaked in deionized water for $24 \mathrm{hr}$ and wetsieved into two size fractions: $\mathrm{a}>63 \mu \mathrm{m}$ fraction and $>125 \mu \mathrm{m}$ fraction. Ichthyoliths (primarily fish teeth, with minor amounts of other skeletal fish debris) were separated under the binocular microscope from the $>125 \mu \mathrm{m}$ size fraction. Additionally, ichthyoliths were separated from the $>63 \mu \mathrm{m}$ size fraction residues of samples from Holes $885 \mathrm{~A}$ and $886 \mathrm{~B}$ (residues provided courtesy of E. Arnold). Only the cleanest and most pristine specimens were selected for analysis. Because of the small size of the ichthyoliths, initially no pretreatment was performed other than rinsing in distilled water. A pretreatment step was later added for several of the larger samples from Core 145$886 \mathrm{C}-6 \mathrm{H}$, owing to surface contamination.

\section{Analytical Methods}

The ichthyoliths were initially dissolved in $4 \mathrm{~N}$ nitric acid. For samples weighing more than $100 \mu \mathrm{g}$, an aliquot was taken for analysis of the concentrations of $\mathrm{Sr}$ and $\mathrm{Rb}$ using isotope dilution methods on the mass spectrometer. Aliquots were not taken from samples weighing less than $100 \mu \mathrm{g}$ because it was feared the sample size would be too small to provide enough $\mathrm{Sr}$ for isotopic analyses (minimum sample size is $100 \mathrm{ng} \mathrm{Sr}$ ). Most samples were composed of 3 to 10 ichthyoliths, with a total weight of between 40 and $200 \mu \mathrm{g}$. Individual ichthyoliths weighed only 10 to $40 \mu \mathrm{g}$ (with the exception of the sporadic large tooth), and thus could not be analyzed separately.

The remaining solution was passed through an ion-exchange column to separate and purify $\mathrm{Sr}$. For isotopic analyses, $100 \mathrm{ng}$ of $\mathrm{Sr}$ in a tantalum-oxide-phosphoric acid slurry was evaporated and oxidized onto a rhenium filament, and the ${ }^{87} \mathrm{Sr} /{ }^{86} \mathrm{Sr}$ ratios were measured on a VG Sector 354 multicollector mass spectrometer at the Center of Isotope Geochemistry, University of California, Berkeley. Some samples were measured in duplicate or triplicate, if the sample size was large enough. The ${ }^{87} \mathrm{Sr} /{ }^{86} \mathrm{Sr}$ ratios were normalized to the EN-1 carbonate standard (a modern Tridacna shell), which has an average ${ }^{87} \mathrm{Sr} /{ }^{86} \mathrm{Sr}$ ratio of 0.709175 , and the NBS 987 strontium standard, which has a ${ }^{87} \mathrm{Sr} /{ }^{86} \mathrm{Sr}$ ratio of 0.710275 . Five standards were run with every set of 15 samples. The $2 \sigma$ uncertainty in the ${ }^{87} \mathrm{Sr} /{ }^{86} \mathrm{Sr}$ ratio is \pm 0.00001 in the ${ }^{87} \mathrm{Sr} /{ }^{86} \mathrm{Sr}$ ratio, based on standard reproducibility.

After the initial strontium isotopic results were obtained, it became apparent that the ${ }^{87} \mathrm{Sr} /{ }^{86} \mathrm{Sr}$ ratios of most of the samples from the bottom of Core 145-886B-7H, and samples below Section 145-886C$8 \mathrm{H}-1$ were heavier than the younger samples upcore (Table 1). $\mathrm{Be}-$ cause the ${ }^{87} \mathrm{Sr} /{ }^{86} \mathrm{Sr}$ ratio in seawater increased throughout the Late Cretaceous and Cenozoic to the present (with only a slight increase at the Cretaceous/Tertiary boundary: Fig. 2), the increase in the ${ }^{87} \mathrm{Sr} /{ }^{86} \mathrm{Sr}$ ratio with depth was suspected to represent either diagenetic alteration/recrystallization or contamination from another mineral phase with a high ${ }^{87} \mathrm{Sr} /{ }^{86} \mathrm{Sr}$ ratio.

Inspection of ichthyoliths from Core $145-886 \mathrm{C}-8 \mathrm{H}$ under the binocular microscope and SEM revealed that the surfaces of many of the ichthyoliths had a brown coating, and the triangular teeth with a central cavity were also filled with brown clay (Pls. 1 and 2). In order to determine if the anomalously high ${ }^{87} \mathrm{Sr} /{ }^{86} \mathrm{Sr}$ ratios in the teeth resulted from leaching of a clay mineral phase during dissolution, a pretreatment step was added to clean the tooth surface by etching with acetic acid. Another set of ichthyolith samples from Core $145-886 \mathrm{C}-8 \mathrm{H}$ were repicked, avoiding all triangular teeth with a central cavity filled with clay. The samples were ultrasonicated in $4 \mathrm{~N}$ acetic acid for 30 min and sieved through a small Teflon sieve. The samples were then ultrasonically treated twice in deionized water for $60 \mathrm{~min}$ and dried under a heat lamp. The ichthyoliths were again inspected under the microscope, and only the cleanest one with unfilled cavities were selected for $\mathrm{Sr}$ isotopic analyses. During the pretreatment step, partial or total dissolution of several of the samples indicated that they had been recrystallized to carbonate. The samples were then dissolved in $1.5 \mathrm{~N} \mathrm{HCl}$, rather than nitric acid, to prevent substantial leaching of any remaining clays, centrifuged, and dried them under a heat lamp for $15 \mathrm{~min}$.

\section{RESULTS AND DISCUSSION Ichthyolith Types}

The primary objective of ichthyolith identification was to search for index fossils to differentiate Late Cretaceous and Cenozoic ichthyoliths, owing to poor stratigraphic resolution of the strontium isotopic seawater curve through much of this period (Eocene-late Cretaceous: Fig. 2). This decision was also made to help verify the interpretation of the anomalous iridium peak at the Cretaceous/Tertiary boundary by Kyte et al. (this volume) at the top of Core 145$886 \mathrm{C}-8 \mathrm{H}$. Because the ${ }^{87} \mathrm{Sr} /{ }^{86} \mathrm{Sr}$ ratios in ichthyoliths below this level in Core $8 \mathrm{H}$ (prior to pretreatment) were anomalously high, I also wanted to inspect the ichthyoliths in more detail in the interval below $65 \mathrm{~m}$ below seafloor (mbsf).

Representative ichthyolith types used for $\mathrm{Sr}$ isotopic analyses are depicted in SEM photographs (PIs. 1-4). In samples from Core 145$886 \mathrm{C}-8 \mathrm{H}$ (at and below the anomalous iridium peak), several distinctive ichthyolith subtypes unique to the Late Cretaceous were found (Pl. 1). These include Triangle long incline, Kite-shaped elongate prominence, Central striated triangle, Narrow triangle sharply pointed, and Triangle square incline. In addition, a number of forms that were found are similar to undescribed forms from an Upper Cretaceous sample from GPC-3 (Doyle and Riedel, 1979: pls. 3, 8, and 9). Further, several ichthyolith forms found at Sites 885 and 886 (Pls. 2 and 4) were not depicted previously in the literature.

In younger samples, the ichthyoliths I was able to identify confirm in a general way the $\mathrm{Sr}$ isotopic ages (Pl. 5). For example, in Section $145-886 \mathrm{C}-7 \mathrm{H}-3$, the $\mathrm{Sr}$ isotopic age was $21 \mathrm{Ma}$. Ichthyoliths identified include Narrow triangle ragged base (early Miocene to Holocene), Triangle pointed margin ends (Paleocene to mid-Miocene), and Long triangle short incline (Miocene). In Section 7H-4 (with a $\mathrm{Sr}$ isotopic age of $29 \mathrm{Ma}$ ), ichthyolith samples identified include Wide triangle straight inbase (early Eocene to Holocene), Triangle medium wing (early Paleocene to mid-Miocene), and Plain and lined lanceolate (late Eocene to early Oligocene: Pl. 1). In Section 7H-5 (with a $\mathrm{Sr}$ isotopic age of $33 \mathrm{Ma}$ ), ichthyolith samples identified include Flexed triangle (early Oligocene to Holocene), Straight flared triangle (late Eocene to Oligocene) and several undescribed forms from a late Eocene to Oligocene sample from GPC-3 (Doyle and Riedel, 1979: pl. 1). None of the samples contained ichthyoliths unique to the Paleocene or Eocene, such as Triangle curved base or Triangle broad wing.

\section{Ichthyolith Abundances}

The triangular ichthyoliths were counted in all 155 5- and 6-cm ${ }^{3}$ residue samples from Holes $885 \mathrm{~A}$ and $886 \mathrm{~B}$ (provided by E. Arnold) in the $>63-\mu \mathrm{m}$ size fraction. The number of triangular ichthyoliths per sample from Holes $885 \mathrm{~A}$ and $886 \mathrm{~B}$ was plotted vs. composite depth (Fig. 3). The younger samples from Unit I (Quaternary to Pliocene claystone) contained few (1 to 4 ) or no ichthyoliths. In Unit II (Pliocene to upper Miocene diatom ooze), no ichthyoliths were found in the upper $20 \mathrm{~m}$ of the unit, but the numbers gradually increased below about $48 \mathrm{mbsf}$. The ichthyolith abundances sharply increased in Subunit IIIa (claystone) at about 54 mbsf (composite depth), and peaked between 55 and 58 mbsf (Fig. 3). Abundances gradually declined between 62 and 72 mbsf in Subunit IIIb (distal hydrothermal precipitates).

The primary factor controlling the distribution of ichthyoliths is presumably the dilution of the ichthyoliths from the high flux of biogenic silica (diatoms ooze) in Unit II, although the increase in ichthy- 
Table 1. Depth and $\mathrm{Sr}$ isotopic data for ichthyolith samples from Holes $885 \mathrm{~A}, 886 \mathrm{~B}$, and $886 \mathrm{C}$.

\begin{tabular}{|c|c|c|c|c|c|c|c|c|c|c|}
\hline \multirow{2}{*}{$\begin{array}{l}\text { Core, section, } \\
\text { interval }(\mathrm{cm})\end{array}$} & \multirow{2}{*}{$\begin{array}{l}\text { Depth } \\
\text { (mbsf) }\end{array}$} & \multirow{2}{*}{$\begin{array}{l}\text { Comp. } \\
\text { depth } \\
\text { (mbsf) }\end{array}$} & \multicolumn{3}{|c|}{${ }^{87} \mathrm{Sr} /{ }^{86} \mathrm{Sr}$ analyses } & \multirow[b]{2}{*}{ Average } & \multirow{2}{*}{\multicolumn{2}{|c|}{$\begin{array}{c}{ }^{87} \mathrm{Sr} /{ }^{86} \mathrm{Sr} \\
\text { (acetic-acid } \\
\text { pretreated) }\end{array}$}} & \multirow[b]{2}{*}{ $\pm 2 \sigma$} & \multirow{2}{*}{$\begin{array}{l}\text { Age } \\
\text { (Ma) }\end{array}$} \\
\hline & & & 1 & 2 & 3 & & & & & \\
\hline \multicolumn{11}{|l|}{$145-885 \mathrm{~A}-$} \\
\hline $5 \mathrm{H}-6,125-130$ & 41.85 & & 0.708953 & & & 0.708953 & 11 & & & \\
\hline $6 \mathrm{H}-1,125-130$ & 43.85 & 51.7 & 0.708989 & & & 0.708989 & 11 & & & 5.7 \\
\hline $6 \mathrm{H}-2,50-55$ & 44.60 & 52.7 & 0.708959 & & & 0.708959 & 11 & & & 5.9 \\
\hline $6 \mathrm{H}-4,50-55$ & 47.60 & 55.2 & 0.708344 & 0.708340 & & 0.708342 & 10 & & & 21.3 \\
\hline $6 \mathrm{H}-4,125-130$ & 48.35 & 55.9 & 0.708469 (a) & & & 0.708469 & 10 & & & 19.4 \\
\hline $6 \mathrm{H}-5,50-55$ & 49.10 & 59.7 & $0.708038(a)$ & & & 0.708038 & 16 & & & 30.2 \\
\hline $6 \mathrm{H}-7,50-55$ & 51.85 & 68.0 & 0.708027 & & & 0.708027 & 13 & & & \\
\hline $7 \mathrm{H}-\mathrm{CC}$ & 54.00 & 71.0 & 0.707519 & & & 0.707519 & 21 & & & 79.0 \\
\hline \multicolumn{11}{|l|}{ 145-886B- } \\
\hline $7 \mathrm{H}-2,47-52$ & 51.27 & 52.9 & 0.708981 & & & 0.708981 & 24 & & & 6.5 \\
\hline $7 \mathrm{H}-3,135-140$ & 53.67 & 55.4 & 0.708860 & 0.708857 & & 0.708859 & 10 & & & 11.3 \\
\hline $7 \mathrm{H}-4,47-52$ & 54.27 & 55.6 & 0.708888 & 0.708872 & & 0.708880 & 12 & & & 11.1 \\
\hline $7 \mathrm{H}-4,125-130$ & 55.05 & 56.3 & 0.708193 (a) & & & 0.708193 & 14 & & & 24.0 \\
\hline $7 \mathrm{H}-4,135-140$ & 55.17 & 56.5 & 0.708351 & 0.708390 & & 0.708375 & 14 & & & 21.5 \\
\hline $7 \mathrm{H}-5,120-125$ & 56.52 & 58.1 & 0.708117 & 0.708093 & & 0.708105 & 15 & & & 27.8 \\
\hline $7 \mathrm{H}-6,140-145$ & 58.20 & 59.7 & 0.708021 & 0.708011 & 0.708008 & 0.708012 & 10 & & & 30.7 \\
\hline $7 \mathrm{H}-7,47-52$ & 58.77 & 60.2 & 0.707970 & $0.708006(a)$ & & 0.707988 & 15 & & & 31.3 \\
\hline $7 \mathrm{H}-7,64-69$ & 58.94 & 60.4 & 0.708006 & 0.707989 & & 0.707997 & 12 & & & 31.2 \\
\hline $7 \mathrm{H}-\mathrm{CC}$ & 59.20 & 60.6 & 0.708067 & 0.708072 & & 0.708067 & 10 & & & b \\
\hline $8 \mathrm{H}-1,68-73$ & 59.50 & 61.2 & 0.708028 & 0.708003 & & 0.708015 & 13 & & & b \\
\hline $8 \mathrm{H}-\mathrm{CC}$ & 61.00 & 61.9 & 0.707961 & 0.707955 & & 0.707958 & 10 & & & 32.5 \\
\hline $9 \mathrm{X}-\mathrm{CC}$ & 62.00 & 62.9 & 0.708120 & 0.708110 & 0.708120 & 0.708112 & 10 & & & b \\
\hline \multicolumn{11}{|l|}{$145-886 \mathrm{C}$ - } \\
\hline $6 \mathrm{H}-4,100-105$ (c) & 50.30 & 49.0 & & & & 0.708979 & 45 & & & 5.8 \\
\hline $6 \mathrm{H}-7,60-65$ (c) & 54.40 & 54,4 & & & & 0.708956 & 24 & & & 6.1 \\
\hline $7 \mathrm{H}-2,135-140$ & 57.10 & 54.8 & 0.708876 & & & 0.708876 & 14 & & & 11.0 \\
\hline $7 \mathrm{H}-3,11-16(\mathrm{c})$ & 57.41 & 55.0 & & & & 0.708876 & 13 & & & 11.0 \\
\hline $7 \mathrm{H}-3,135-140$ & 58.65 & 56.1 & 0.708377 & 0.708355 & & 0.708366 & 10 & & & 21.0 \\
\hline $7 \mathrm{H}-4,135-140$ & 60.17 & 57.6 & 0.708084 & & & 0.708084 & 11 & & & 28.5 \\
\hline $7 \mathrm{H}-5,120-125$ & 61.52 & 58.9 & 0.707905 & & & 0.707905 & 10 & & & 34.0 \\
\hline $7 \mathrm{H}-6,10-15$ (c) & 61.92 & 59.3 & & & & 0.707995 & 17 & & & b \\
\hline $7 \mathrm{H}-6,135-140$ & 63.10 & 60.5 & & & & & & & & \\
\hline $8 \mathrm{H}-1,135-140$ & 65.10 & 63.2 & 0.707917 & 0.707900 & & 0.707908 & 10 & & & 65.0 \\
\hline $8 \mathrm{H}-2,10-15(\mathrm{c})$ & 65.42 & 63.6 & & & & 0.707967 & 17 & & & b \\
\hline $8 \mathrm{H}-2,135-140$ & 66.67 & 64.8 & 0.708158 & 0.708204 & 0.708194 & 0.708184 & 10 & & & b \\
\hline $8 \mathrm{H}-3,135-140$ & 68.17 & 66.2 & 0.708145 & 0.708125 & & 0.708135 & 10 & 0.707914 & 11 & b \\
\hline $8 \mathrm{H}-4,30-35$ (c) & 68.62 & 66.8 & 0.707779 & & & 0.707779 & 15 & & & 68.5 \\
\hline $8 \mathrm{H}-4,45-50(\mathrm{c})$ & 68.77 & 66.9 & 0.707728 & & & 0.707728 & 15 & & & 71.5 \\
\hline $8 \mathrm{H}-4,135-140$ & 69.62 & 678 & & & & & & 0.707719 & 13 & 72.5 \\
\hline $8 \mathrm{H}-5,120-125$ & 71.00 & 69.7 & & & & & & 0.707595 & 11 & 76.5 \\
\hline $8 \mathrm{H}-6,50-55 \mathrm{a}(\mathrm{c})$ & 71.80 & 70.1 & 0.707647 & & & 0.707647 & 20 & & & 74.5 \\
\hline $8 \mathrm{H}-6,50-55 \mathrm{~b}(\mathrm{c})$ & 71.80 & 70.1 & 0.707839 & & & 0.707839 & 17 & & & b \\
\hline $8 \mathrm{H}-6,85-90$ & 72.15 & 70.3 & & & & & 16 & 0.707927 & 18 & b \\
\hline $8 \mathrm{H}-6,135-140$ & 72.65 & 70.8 & 0.708123 & & & 0.708123 & 17 & & & b \\
\hline \multicolumn{11}{|l|}{ 145-887D- } \\
\hline $4 \mathrm{R}-2,106-110$ & 290.00 & & 0.708310 & 0.708293 & 0.708293 & 0.708294 & 10 & & & 22.2 \\
\hline
\end{tabular}

Notes: $\mathrm{a}=$ analyses with a discrimination below $1.0 ; \mathrm{b}={ }^{87} \mathrm{Sr} /{ }^{86} \mathrm{Sr}$ ratios interpreted to be too high (altered or contaminated); $\mathrm{c}=\mathrm{C}$. Jones analyses, normalized to our NBS Standard $(0.710276)$. Comp. $=$ composite.

olith abundance begins at the bottom of Unit II, and not at the Unit II/ Unit III boundary. Previous studies in pelagic clay cores (such as GPC-3) indicate that ichthyoliths are generally less abundant in sediments younger than the middle Miocene than in older (Cenozoic) pelagic sediments (Edgerton et al., 1977), which is consistent with this study. Ichthyolith abundances are higher in the Oligocene and Eocene sediments in GPC-3, and peak at the Paleocene/Eocene boundary and at the Eocene/Oligocene boundary (Doyle and Riedel, 1979). High phosphate concentrations in GPC-3 and at DSDP Site 576 (Kyte et al., 1993) in upper Paleocene pelagic sediments have been attributed to increased biogenic apatite. Based on the strontium isotopic dating, the peak in ichthyolith concentration seen at Sites 885 and 886 probably corresponds to the late Eocene/early Oligocene peak in GPC-3.

\section{Spherules: Site 886C}

Kyte et al. (this volume) discovered an interval of anomalously high iridium (Ir) concentration, shocked quartz, and spherules at the top of Core $145-886 \mathrm{C}-8 \mathrm{H}$ ( 65.1 and $65.3 \mathrm{mbsf})$. This interval, which was fortuitously sampled aboard ship (Sample 145-886C-8H-1, 135$140 \mathrm{~cm}$ ), contains abundant spherules (about $30 \%$ ), in addition to $\mathrm{Fe}-$ Mn oxide micronodules, ichthyoliths, and minor amounts of quartz and feldspar. Spherules have been found in Cretaceous/Tertiary boundary clay from the central North Pacific (GPC-3: Kyte and Wasson, 1986), DSDP Site 577 (Smit and Romein, 1985), and several other DSDP sites in the Pacific (576, 465, and 596: Kyte et al., 1994). Arguments are made that spherules at DSDP Site 577, 10,000 km away from the Chicxulub crater in Yucatan, Mexico, provide evidence for a Cretaceous/Tertiary impact site in the Pacific Ocean (Robin et al., 1993). Hole 886C represents the farthest north that the spherules have been found in the Pacific Ocean. The mineralogy and chemistry of the spherules will be part of a future study.

Spherules were found in both the $>63 \mu \mathrm{m}$ and $>125 \mu \mathrm{m}$ size fractions, and range between 80 and $800 \mu \mathrm{m}$ in diameter, with an average diameter of $200-400 \mu \mathrm{m}$. Some of the larger spherules were perfectly round, yellow to brownish spheres (Pl. 5), and the smaller ones had more irregular surfaces. Several had an elongated, dumbbell, or teardrop shape (Pl. 6). Many of the spherules were broken open and fragmented, and were either hollow inside or filled with authigenic minerals (Pls. 5 and 6). Some of the outer surfaces of the spherules appeared desiccated and cracked (Pls. 5 and 6).

The spherules appear entirely recrystallized (inside and out). The most common authigenic clay mineral identified filling the spherules was smectite, which has a spheroidal habit with a diameter of about $10 \mu \mathrm{m}$ (Pl. 5). Under high magnification on the SEM, the smectite 


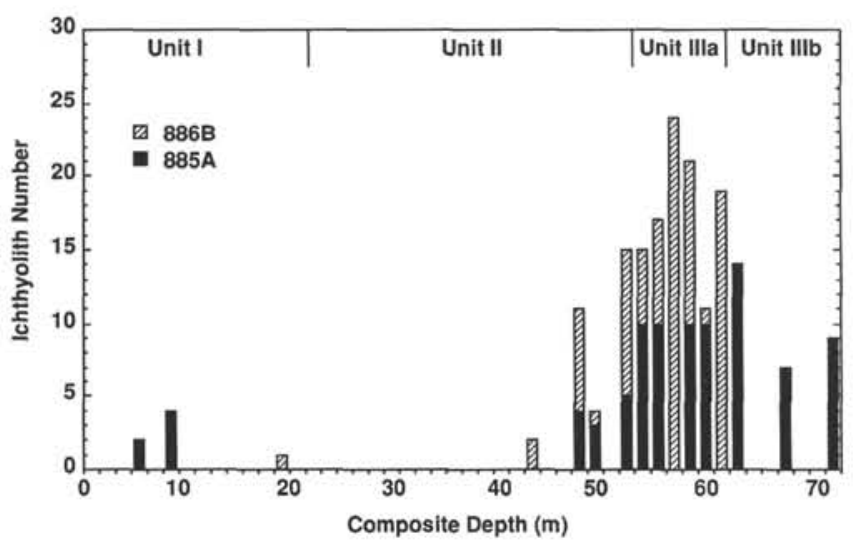

Figure 3. The number of triangular ichthyoliths counted per $5-\mathrm{cm}^{3}$ sample residue ( $>63 \mu \mathrm{m}$ size fraction) plotted against composite depth (Dickens et al., this volume) for Holes $885 \mathrm{~A}$ and $886 \mathrm{~B}$.

surface has a characteristic crenulated or webby texture (PI. 5). Smectite was also found in other spherules from the Pacific Ocean, and is thought to represent the alteration of olivine (Robin et al., 1993). Another mineral filling a spherule has a dendritic texture (Pl. 5), similar in appearance to that described by Smit et al. (1992). The dendritic clays filling spherules recovered from the Cretaceous/Tertiary boundary at DSDP Site 577A (Shatsky Rise, Pacific) were thought to be altered pseudomorphically after clinopyroxene and K-feldspar (Smit et al., 1992).

The ${ }^{87} \mathrm{Sr} /{ }^{86} \mathrm{Sr}$ ratios measured in fish teeth separated from the spherule-rich interval (Sample 145-886C-8H-1, 135-140 cm) had a Rb-corrected ${ }^{87} \mathrm{Sr} /{ }^{86} \mathrm{Sr}$ ratio of 0.707887 , which is within the range of seawater $\mathrm{Sr}$ values measured from deep-sea foraminifers by Hess et al. (1986), but higher than those measured by Swinburne et al. (1994) by 0.00008 (Table 1 and Fig. 2). The sample immediately below this level (from Sample 145-886C-8H-2, 10-15 cm), although pretreated by reductive dissolution, has a higher ${ }^{87} \mathrm{Sr} /{ }^{86} \mathrm{Sr}$ ratio $(0.707967)$. One possible explanation is the addition of radiogenic $\mathrm{Sr}$ to pore fluids during recrystallization of the Cretaceous/Tertiary boundary spherules. Previous studies have shown that Cretaceous/Tertiary boundary spherules have high ${ }^{87} \mathrm{Sr} /{ }^{86} \mathrm{Sr}$ ratios (DePaolo et al., 1983). Spherules from the Jorquera Formation at Caravaca, Spain, had a ${ }^{87} \mathrm{Sr} /{ }^{86} \mathrm{Sr}$ ratio of 0.710123 , and those from GPC-3 had a ${ }^{87} \mathrm{Sr} /{ }^{86} \mathrm{Sr}$ ratio of 0.708913 (DePaolo et al., 1983).

\section{Strontium Isotopic Results}

Samples, sample depths (mbsf and composite depth), ${ }^{87} \mathrm{Sr} /{ }^{86} \mathrm{Sr}$ ratios, $\mathrm{Sr}$ and $\mathrm{Rb}$ concentrations, and ${ }^{87} \mathrm{Rb} /{ }^{86} \mathrm{Sr}$ of samples for which $\mathrm{Rb}$ concentrations were determined, are listed in Tables 1 and 2. The $\mathrm{Sr}$ concentrations range between 1047 and 1733 ppm, and Rb concentrations are between 9 and $89 \mathrm{ppm}$. These are similar to previous $\mathrm{Sr}$ concentrations measured in fish teeth from GPC-3 (800-1600 ppm; Staudigel et al., 1985), but somewhat higher than the Rb concentrations $(0.3$ to $32 \mathrm{ppm})$. The calculated ${ }^{87} \mathrm{Rb} /{ }^{86} \mathrm{Sr}$ ratios for samples range between 0.0124 and 0.2290 (Table 2). The ${ }^{87} \mathrm{Sr} /{ }^{86} \mathrm{Sr}$ ratios for the three holes were plotted vs. composite depth (Fig. 4).

\section{Contamination and Diagenesis}

Several of the samples appeared to have ${ }^{87} \mathrm{Sr} /{ }^{86} \mathrm{Sr}$ ratios that were too high to reflect original seawater, based on their relative position in the stratigraphic sequence and other stratigraphic intervals of known age. These samples occurred primarily below about a composite depth of $63 \mathrm{mbsf}$ in Holes $886 \mathrm{~B}$ and $886 \mathrm{C}$, within the lower- most portion of Subunit IIIa (claystone) and most of Subunit IIIb (distal hydrothermal precipitates).

\section{Surface Contamination}

Contamination of the primary fish tooth apatite by a secondary phase adhered to the surface (i.e., carbonate, Fe-Mn oxides, or silicate clays) can alter the measured ${ }^{87} \mathrm{Sr} /{ }^{86} \mathrm{Sr}$ ratio by contributing leached Sr. The effect any contaminant has on the ichthyolith depends upon its $\mathrm{Sr}$ concentration and ${ }^{87} \mathrm{Sr} /{ }^{86} \mathrm{Sr}$ ratio. It also depends upon the total amount of $\mathrm{Sr}$ in the ichthyolith sample (determined by its size and $\mathrm{Sr}$ concentration).

Measurements of the surface sediments in the Pacific indicate that the continentally derived detrital component has an ${ }^{87} \mathrm{Sr} /{ }^{86} \mathrm{Sr}$ ratios of 0.710 to 0.719 , with the highest ratios $(>0.715)$ occurring on the abyssal plain (Asahara et al., 1994). These high $\mathrm{Sr}$ isotopic values are thought to result from loess supplied from the Asian continent $\left({ }^{87} \mathrm{Sr} /\right.$ ${ }^{86} \mathrm{Sr}$ ratio of about 0.720 ). Volcanic ash has a range of ${ }^{87} \mathrm{Sr} /{ }^{86} \mathrm{Sr}$ ratios of 0.705 to 0.708 .

Hydrothermally-derived Fe-Mn oxides that accumulate close to the hydrothermal source (such as active spreading centers or volcanic arcs) have ${ }^{87} \mathrm{Sr} /{ }^{86} \mathrm{Sr}$ ratios of about 0.702 to 0.705 (Edmond et al., 1979; Albarede et al., 1981; Palmer and Edmond, 1989). Hydrogenous $\mathrm{Fe}-\mathrm{Mn}$ oxides should have ${ }^{87} \mathrm{Sr} /{ }^{86} \mathrm{Sr}$ ratios similar to that of seawater (Futa et al., 1988; Ingram et al., 1990). Distal hydrothermal deposits should have $\mathrm{Sr}$ isotopic ratios between those of hydrothermal and hydrogenous Fe-Mn oxides (e.g., Ingram et al., 1990).

The anomalously high ${ }^{87} \mathrm{Sr} /{ }^{86} \mathrm{Sr}$ ratios measured in untreated samples from Core 145-886C-8H probably result from leaching of a surface coating of Fe-Mn oxides. These have been described as distal hydrothermal precipitates (Dickens and Owen, this volume), and must contain $\mathrm{Sr}$ that had exchanged post-depositionally with younger seawater (with a higher ${ }^{87} \mathrm{Sr} /{ }^{86} \mathrm{Sr}$ ratio). Another possible contaminant in the top of Core $8 \mathrm{H}$ would be contamination from crushed and recrystallized spherules.

The samples from Core $145-886 \mathrm{C}-8 \mathrm{H}$ were pretreated by two different methods to remove the $\mathrm{Fe}-\mathrm{Mn}$ oxide coatings. One method was leaching in $4 \mathrm{~N}$ acetic acid (described above), which effectively etched the outer surface and thereby removed the Fe-Mn coating, as well as any other secondary recrystallized carbonate. The other method was reductive dissolution, which is described in detail by Snoeckx et al. (this volume), which apparently removed the hydrothermal $\mathrm{Fe}$ and $\mathrm{Mn}$ oxide coatings and any other adhered clay material. Both methods removed the $\mathrm{Fe}-\mathrm{Mn}$ coating, and caused the ${ }^{87} \mathrm{Sr} /{ }^{86} \mathrm{Sr}$ ratio in the ichthyoliths to decrease significantly (by 0.0002 to 0.0006 ). However, some of the pretreated samples had ${ }^{87} \mathrm{Sr} /{ }^{86} \mathrm{Sr}$ ratios that were still anomalously high, indicating either incomplete removal of the contaminant, or diagenetic alteration of the sample.

\section{Diagenesis or Recrystallization of Fish Teeth}

Convincing arguments have been made that every fish fossil is a recrystallized pseudomorph of the original fish bone, and the most important factor in determining the final composition of fish fossils is the environment in which they are buried (Kolodny and Luz, 1991). Assuming this to be true, the magnitude and direction of the shift in ${ }^{87} \mathrm{Sr} /{ }^{86} \mathrm{Sr}$ ratio from the original value should depend upon several factors (e.g., Richter and DePaolo, 1987): (1) the timing and rate of recrystallization; (2) the proportion, ${ }^{87} \mathrm{Sr} r{ }^{86} \mathrm{Sr}$ ratio, and $\mathrm{Sr}$ content of the non-carbonate phases in the sediment; (3) the burial depth and sedimentation rate; (4) pore-water chemistry (Shemesh, 1990). In abyssal clay pelagic sediments, which have an exceptionally low sedimentation rate $\left(\leq 0.5 \mathrm{~m} / \mathrm{m} . \mathrm{y}\right.$.), the ${ }^{87} \mathrm{Sr} /{ }^{86} \mathrm{Sr}$ of the pore fluid can become much different from the original values, causing a significant shift in the ${ }^{87} \mathrm{Sr} /{ }^{86} \mathrm{Sr}$ ratios of recrystallizing phosphate and carbonate minerals. 
Table 2. $\mathrm{Rb}$ and $\mathrm{Sr}$ concentrations, ${ }^{\mathrm{R} 7} \mathrm{Rb} /{ }^{86} \mathrm{Sr}$, and $\mathrm{Rb}$-corrected ratios and ages for selected samples.

\begin{tabular}{|c|c|c|c|c|c|c|c|c|c|}
\hline $\begin{array}{l}\text { Core, section, } \\
\text { interval }(\mathrm{cm})\end{array}$ & $\begin{array}{l}\text { Depth } \\
\text { (mbsf) }\end{array}$ & $\begin{array}{l}\text { Composite } \\
\text { depth } \\
\text { (mbsf) }\end{array}$ & $\begin{array}{c}\mathrm{Rb} \\
(\mathrm{ppm})\end{array}$ & $\begin{array}{c}\mathrm{Sr} \\
(\mathrm{ppm})\end{array}$ & ${ }^{87} \mathrm{Rb} /{ }^{86} \mathrm{Sr}$ & $\begin{array}{c}{ }^{87} \mathrm{Sr} /{ }^{86} \mathrm{Sr} \\
\text { average }\end{array}$ & $\begin{array}{l}\text { Age } \\
\text { (Ma) }\end{array}$ & $\begin{array}{c}\mathrm{Rb} \\
\text { corrected } \\
{ }^{87} \mathrm{Sr} /{ }^{86} \mathrm{Sr}\end{array}$ & $\begin{array}{c}\text { Corrected } \\
\text { age } \\
\text { (Ma) }\end{array}$ \\
\hline $\begin{array}{l}145-885 \mathrm{~A}- \\
6 \mathrm{H}-4,50-55 \\
6 \mathrm{H}-6,50-55\end{array}$ & $\begin{array}{l}47.60 \\
50.60\end{array}$ & $\begin{array}{l}55.2 \\
66.5\end{array}$ & $\begin{array}{r}6.0 \\
12.1\end{array}$ & $\begin{array}{l}1408 \\
1047\end{array}$ & $\begin{array}{l}0.0124 \\
0.0335\end{array}$ & $\begin{array}{l}0.708342 \\
0.708027\end{array}$ & $\begin{array}{l}21.3 \\
75 \text { (a) }\end{array}$ & $\begin{array}{l}0.708346 \\
0.707987\end{array}$ & $\begin{array}{l}b \\
b\end{array}$ \\
\hline $\begin{array}{l}145-886 \mathrm{~B}- \\
7 \mathrm{H}-4,47-52 \\
7 \mathrm{H}-7,47-52\end{array}$ & $\begin{array}{l}54.27 \\
58.77\end{array}$ & $\begin{array}{l}55.6 \\
60.2\end{array}$ & $\begin{array}{l}32.2 \\
89.9\end{array}$ & $\begin{array}{l}1344 \\
1135\end{array}$ & $\begin{array}{l}0.0693 \\
0.2290\end{array}$ & $\begin{array}{l}0.708880 \\
0.707988\end{array}$ & $\begin{array}{l}11.1 \\
31.3\end{array}$ & $\begin{array}{l}0.708870 \\
0.707888\end{array}$ & $\begin{array}{l}11.3 \\
34.2\end{array}$ \\
\hline $\begin{array}{l}145-886 \mathrm{C}- \\
8 \mathrm{H}-1,135-140 \\
8 \mathrm{H}-2,135-140 \\
8 \mathrm{H}-6,135-140\end{array}$ & $\begin{array}{l}65.10 \\
66.67 \\
72.65\end{array}$ & $\begin{array}{l}63.2 \\
64.8 \\
70.8\end{array}$ & $\begin{array}{l}11.6 \\
46.5 \\
18.8\end{array}$ & $\begin{array}{l}1733 \\
1097 \\
1439\end{array}$ & $\begin{array}{l}0.0195 \\
0.1226 \\
0.0377\end{array}$ & $\begin{array}{l}0.707908 \\
0.708184 \\
0.708123\end{array}$ & $\begin{array}{l}65.0 \\
68 \text { (a) } \\
78 \text { (a) }\end{array}$ & $\begin{array}{l}0.707887 \\
0.708064 \\
0.708083\end{array}$ & $\begin{array}{c}65.0 \\
\text { b } \\
\text { b }\end{array}$ \\
\hline
\end{tabular}

Notes: $\mathrm{a}=$ age interpolated from adjacent samples; $\mathrm{b}={ }^{87} \mathrm{Sr} /{ }^{86} \mathrm{Sr}$ ratio still too high because of contamination or diagenesis to give age information.

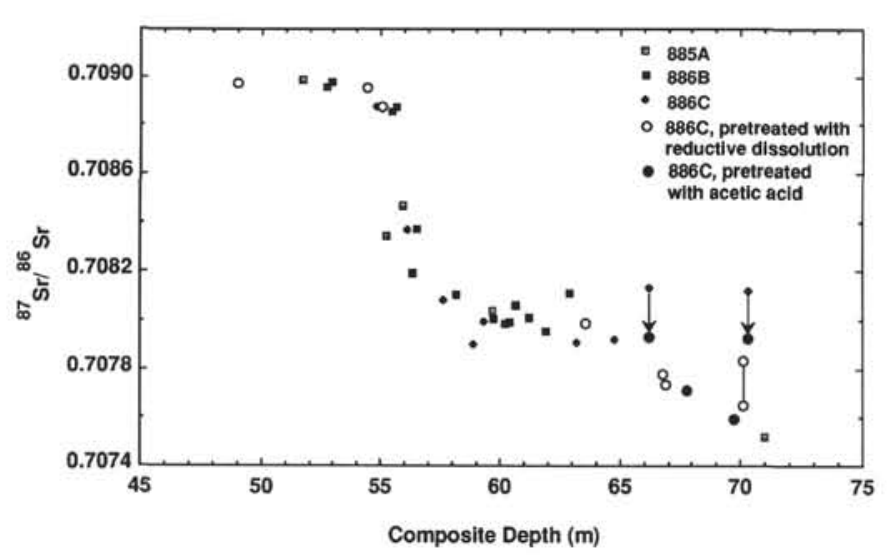

Figure 4. Strontium isotopic ratios plotted against composite depth (Dickens et al., this volume) for Holes $885 \mathrm{~A}, 886 \mathrm{~B}$, and $886 \mathrm{C}$.

It has also been shown that post-depositional recrystallization (by dissolution and reprecipitation) of ancient fish teeth causes an increase in crystallinity (by the transformation of carbonate-hydroxyapatite to francolite, or carbonate fluorapatite), and a corresponding decrease in $\mathrm{Sr}$ content (Shemesh, 1990). The fish tooth apatite samples with the highest crystallinity index (as determined by infrared spectroscopy) had $\mathrm{Sr}$ concentrations below $2000 \mathrm{ppm}$, whereas those with a less ordered structure had $\mathrm{Sr}$ concentrations between 2000 and $5000 \mathrm{ppm}$. Shemesh (1990) also suggested that the pore-water chemistry (such as Eh) is another important factor controlling the preservation of the organic matrix of the fish remains. The total organic carbon contents in Unit III were very low $(0.02 \%$ to $0.08 \%)$, and the presence of $\mathrm{Fe}-\mathrm{Mn}$ oxides indicates a highly oxidizing environment.

There is evidence of recrystallization of some of the older ichthyoliths in this study. For example, during the pretreatment step with $4 \mathrm{~N}$ acetic acid, some of the older ichthyoliths were partially or completely dissolved. Also, the $\mathrm{Sr}$ concentrations for all the samples measured were less than $2000 \mathrm{ppm}$, which is much lower than those reported from other studies, typically between 2000 and $5000 \mathrm{ppm}$ (Shemesh, 1990; Ingram, 1992; Ingram et al., 1994; Swinburne et al., in press), although within the range reported for ichthyoliths from GPC-3 (Staudigel et al., 1985).

\section{Formation of ${ }^{87} \mathrm{Sr}$ in the Fish Teeth}

If $\mathrm{Rb}$ is incorporated during formation of the primary apatite or during subsequent recrystallization, the decay of ${ }^{87} \mathrm{Rb}$ to ${ }^{87} \mathrm{Sr}$ may produce a measurable effect on the ${ }^{87} \mathrm{Sr} /{ }^{86} \mathrm{Sr}$ ratio in the ichthyoliths, depending on the ${ }^{87} \mathrm{Rb} /{ }^{86} \mathrm{Sr}$ ratio and age of the sample. Although some previous studies have shown that this is not usually a problem (Staudigel et al., 1985; Swinburne et al., in press), measurements of up to $32 \mathrm{ppm} \mathrm{Rb}$ have previously been reported for ichthyolith samples (Staudigel et al., 1985; Ingram et al., 1994).

Several of the samples had a high Rb concentration (up to $89 \mathrm{ppm}$ ) and relatively high ${ }^{87} \mathrm{Rb} /{ }^{86} \mathrm{Sr}$ ratios (between 0.019 and 0.22 : Table 2). For these samples, the initial ${ }^{87} \mathrm{Sr} /{ }^{86} \mathrm{Sr}$ ratios were calculated to be between 0.00001 and 0.00092 lower than that measured, with corresponding age corrections of 0.2 to 3.4 m.y. (Table 2).

\section{Reworking of Ichthyoliths and Bioturbation}

Another potential problem in these sediments is the potential for reworking of older ichthyoliths into younger sediments. This has been previously noted in pelagic clay sequences, based on recognition of older index ichthyoliths in younger sediments (Doyle and Riedel, 1979). However, because the most obvious problem was one of increased ${ }^{87} \mathrm{Sr} /{ }^{86} \mathrm{Sr}$ ratios (whereas the seawater ${ }^{87} \mathrm{Sr} /{ }^{86} \mathrm{Sr}$ ratio decreases with age for much of the past $150 \mathrm{~m} . \mathrm{y}$.), this is probably not the primary problem. Some of the small age incongruities between adjacent samples (for example, small age reversals were observed at Hole 885A in Samples 6H-4, 50-55 cm, and 125-130 cm, and 7H-4, $125-130 \mathrm{~cm}$, and $135-140 \mathrm{~cm}$ ) may have been produced by bioturbation of the sediments, particularly in the pelagic clays, which typically have extremely low sedimentation rates $(<0.5 \mathrm{~m} / \mathrm{m}$.y.). All cores were described as slightly bioturbated throughout.

\section{Age Determinations}

Because the contaminant or diagenetic alteration of the ichthyoliths apparently causes an increase in the ${ }^{87} \mathrm{Sr} /{ }^{86} \mathrm{Sr}$ ratio, the best estimates of minimum age of the samples is determined by the lowest ${ }^{87} \mathrm{Sr} /{ }^{86} \mathrm{Sr}$ ratios, by comparison with the seawater $\mathrm{Sr}$ reference curve (Tables 1 and 2; and Fig. 5). The age uncertainties are complicated, encompassing the uncertainty of the ${ }^{87} \mathrm{Sr} /{ }^{86} \mathrm{Sr}$ ratio measurement, the slope of the $\mathrm{Sr}$ isotopic reference curve at any particular time, and the other problems discussed above (diagenetic alteration, contamination, and bioturbation). However, it is encouraging that the ages obtained from the three cores (including samples analyzed by C. Jones at University of Michigan), when plotted against composite depth, agree fairly well (Fig. 5).

The ages determined by strontium isotopic ratios from the uppermost portion of the section are consistent with radiolarian, diatom, and magnetic reversals that give a maximum age of late Miocene (Fig. 6). At Hole 885A, the youngest age (Sample $6 \mathrm{H}-1,125-130 \mathrm{~cm}$, at a depth of $43.85 \mathrm{mbsf}$ and a composite depth of $51.8 \mathrm{mbsf}$ ) is 5.7 $\mathrm{Ma} \pm 0.5$, which is about $1 \mathrm{~m}$.y. younger than that obtained by radiolarian biostratigraphy (with a minimum age of $6.75 \mathrm{Ma}$; Morley, this volume). In Hole $886 \mathrm{~B}$, the youngest sample dated was $7 \mathrm{H}-3$, $135-140 \mathrm{~cm}$, at a depth of $53.67 \mathrm{mbsf}$, with an age of $11.3 \mathrm{Ma}$. In 


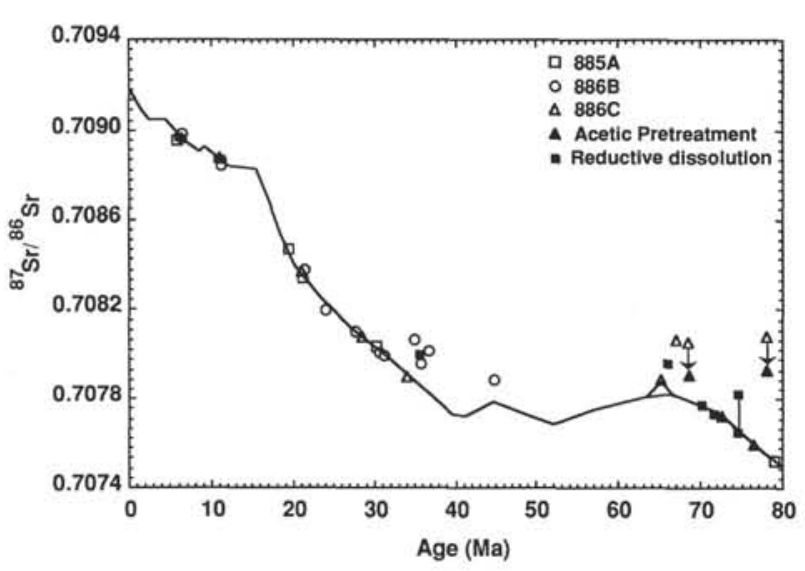

Figure 5. Strontium isotopic ratios plotted on the $\mathrm{Sr}$ isotope seawater reference curve.

Hole $886 \mathrm{C}$, the youngest age $(6 \mathrm{H}-4,100-105 \mathrm{~cm}$, composite depth of $50.3 \mathrm{mbsf}$ ) was dated at $5.8 \mathrm{Ma}$, again, slightly younger than the radiolarian age (Fig. 6).

The maximum age of the pelagic clay sequence (Unit III) at Sites 885 and 886 is constrained by the age of the underlying basalt cobbles of Unit IV, dated by ${ }^{40} \mathrm{Ar} /{ }^{39} \mathrm{Ar}$ at $80 \mathrm{Ma}$ (Keller, 1993). At Hole 885A, this age is confirmed by ichthyoliths from Section 7H-CC (which contained mostly basalt cobbles), which has a ${ }^{87} \mathrm{Sr} /{ }^{86} \mathrm{Sr}$ ratio of 0.707519 , corresponding to an age of $79 \mathrm{Ma}$. At Hole 886B, the lowest ${ }^{87} \mathrm{Sr} /{ }^{86} \mathrm{Sr}$ ratio is 0.707958 , which has an age of $32.5 \mathrm{Ma}$. At Hole $886 \mathrm{C}$, the lowest ${ }^{87} \mathrm{Sr} /{ }^{86} \mathrm{Sr}$ ratio measured in Core $8 \mathrm{H}$ (in Sample $8 \mathrm{H}$ $5,120-125$, at $71 \mathrm{mbsf}$ ) is 0.707595 , with a corresponding age of $76.5 \mathrm{Ma}$. This age is consistent with three samples above it, which also gave Late Cretaceous ages (72.5, 71.5, and $68.5 \mathrm{Ma}$, from depths of $69.62,68.77$, and $68.62 \mathrm{mbsf}$, respectively).

\section{Sedimentation Rates}

Sites 885 and $886,2.2 \mathrm{~km}$ apart, comprise the same sedimentary sequence but have different thicknesses. The sediment thickness at Hole $885 \mathrm{~A}$ is $52 \mathrm{~m}$, whereas at Site 886 it is $71.9 \mathrm{~m}$. At Hole $886 \mathrm{C}$, linear sedimentation rates for Unit II, based on $\mathrm{Sr}$ isotopic ages, are high $(13.67 \mathrm{~m} / \mathrm{m} . \mathrm{y}$.). The rates is constrained by magnetostratigraphy, radiolarian and diatom biostratigraphy, and, in the lowermost portion of the unit, $\mathrm{Sr}$ isotope stratigraphy on four ichthyolith samples. In Subunit IIIa (clay and claystone), the sedimentation rate drops to between 0.24 and $0.28 \mathrm{~m} / \mathrm{m}$.y. For the interval with the recovery gap of at least $0.75 \mathrm{~m}$ (between Cores $7 \mathrm{H}$ and $8 \mathrm{H}$ at Hole $886 \mathrm{C}$ ), an interval of time of about $31 \mathrm{~m} . \mathrm{y}$. is represented by a minimum of $3.6 \mathrm{~m}$ of sediment, giving a minimum sedimentation rate of $0.14 \mathrm{~m} / \mathrm{m}$.y. Unfortunately, the $\mathrm{Sr}$ isotopic data do not help constrain the age of the missing section between Cores $7 \mathrm{H}$ and $8 \mathrm{H}$ in Hole $886 \mathrm{C}$, other than placing it between 34 and $65 \mathrm{Ma}$, owing to poor age control through the Paleogene. In the Upper Cretaceous (below 63 mbsf) at Hole $886 \mathrm{C}$, the linear sedimentation rate increases to $0.51 \mathrm{~m} /$ m.y., most likely as a result of the increased flux of distal hydrothermal precipitates (Dickens and Owen, this volume).

The sedimentation rates determined by $\mathrm{Sr}$ isotope stratigraphy are generally inversely correlated with the cobalt concentrations measured at Hole $886 \mathrm{C}$ (Kyte, this volume) as expected, because the Co accumulation rate is constant (Kyte et al., 1993). Co concentrations were lowest in Unit II (diatom ooze), which had the highest sedimentation rate, and were highest in the pelagic clay Subunit (IIIa), between 57 and $63 \mathrm{mbsf}$, and then slightly decreased in Subunit IIIb (distal hydrothermal precipitates).

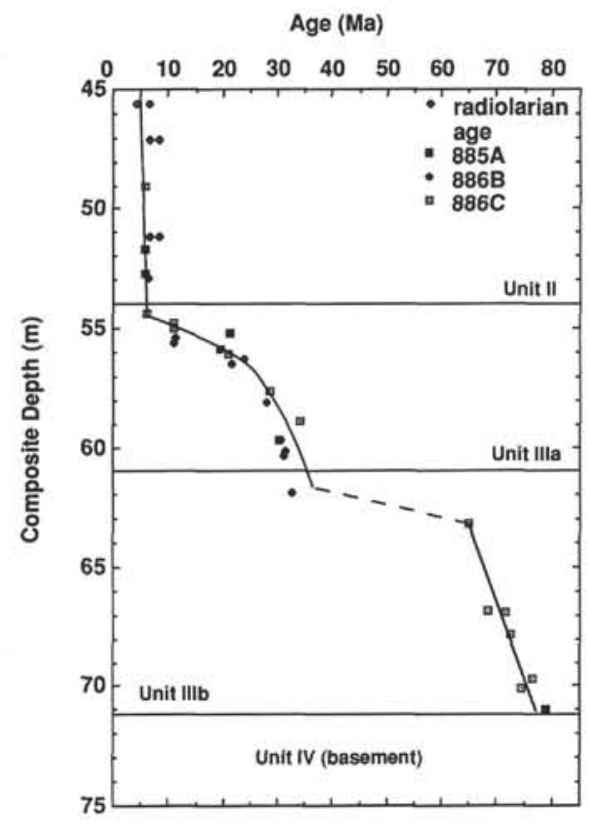

Figure 6. Ages for Sites 885 and 886 plotted against composite depth.

The sedimentation rates determined in this study agree with those determined for clays deposited elsewhere in the North Pacific Ocean at abyssal depths. For example, linear sedimentation rates in GPC-3 were calculated to be about $0.2 \mathrm{~m} / \mathrm{m}$.y. for the mid-Cenozoic (midPaleocene to the mid-Miocene; Kyte et al., 1993). At DSDP Site 576, sedimentation rates varied between 0.4 to $0.5 \mathrm{~m} / \mathrm{m}$.y. (Heath, Burckle, et al., 1985; Janecek, 1985).

\section{CONCLUSIONS}

Ichthyoliths from the Leg 145 North Pacific transect were separated from pelagic clay recovered at ODP Sites 885 and 886 and dated with high-precision ${ }^{87} \mathrm{Sr} /{ }^{86} \mathrm{Sr}$ measurements. The ${ }^{87} \mathrm{Sr} /{ }^{86} \mathrm{Sr}$ ratios in fish teeth from the base of the clay unit (Unit III) from Holes 885A and $886 \mathrm{C}$ indicate deposition of the clay began in the Late Cretaceous (between 76.5 and $79.0 \mathrm{Ma}$ ).

In Hole $886 \mathrm{C}$, ichthyolith identifications and ${ }^{87} \mathrm{Sr} /{ }^{86} \mathrm{Sr}$ ratio measurements, as well as the presence of spherules from an interval with an anomalously high iridium concentration (identified and described by Kyte et al., this volume) confirm an age of the Cretaceous/Tertiary boundary. Untreated ichthyolith samples in Core 145-886C-8H, below the Cretaceous/Tertiary boundary, had anomalously high ${ }^{87} \mathrm{Sr} /$ ${ }^{86} \mathrm{Sr}$ ratios. After leaching some samples with acetic acid (and the reductive dissolution of others) to remove adhered Fe-Mn oxides and clays, the ${ }^{87} \mathrm{Sr} /{ }^{86} \mathrm{Sr}$ ratios measured in the ichthyoliths (presumably reflecting original seawater) were much lower, indicating deposition during the Late Cretaceous beginning at $76.5 \mathrm{Ma}$.

The ${ }^{87} \mathrm{Sr} /{ }^{86} \mathrm{Sr}$ ratios of fish teeth from the top of Unit III $(0.708959)$, deposited just below the diatom-rich unit (II), indicate an age of late Miocene (6.1 Ma) from the transition from slowly accumulating pelagic clay to the more rapid accumulation of diatom ooze, which is consistent with radiolarian and diatom biostratigraphy.

The average sedimentation rate of the pelagic clay unit at Hole $886 \mathrm{C}$ varies from $0.24 \mathrm{~m} / \mathrm{m}$.y. in Subunit IIIa, to an increased rate of $0.51 \mathrm{~m} / \mathrm{m}$.y. in Subunit IIIb, perhaps owing to increased hydrothermal influx. These rates are consistent with previously determined sedimentation rates in North Pacific pelagic clays. 


\section{REFERENCES*}

Albarede, F., Michard, A., Minster, J.F., and Michard, G., 1981. ${ }^{87} \mathrm{Sr} /{ }^{86} \mathrm{Sr}$ ratios in hydrothermal water and deposits from the East Pacific Rise at $21^{\circ}$ N. Earth Planet. Sci. Lett., 55:229-236.

Asahara, Y., Tanaka, T., Kamioka, H., and Nishimura, A., 1994. Continental nature of ${ }^{87} \mathrm{Sr} r{ }^{86} \mathrm{Sr}$ ratios in the North Central Pacific sediments. 8th Int. Conf. Geochron., Cosmochron., Isotop. Geochem., Berkeley, CA. (Abstract)

Burke, W.H., Denison, R.E., Hetherington, E.A., Koepnick, R.B., Nelson, H.F., and Otto, J.B., 1982. Variation of seawater ${ }^{87} \mathrm{Sr}{ }^{86} \mathrm{Sr}$ throughout Phanerozoic time. Geology, 10:516-519.

Capo, R.C., and DePaolo, D.J., 1990. Seawater strontium isotopic variations from 2.5 million years ago to the present. Science, 249:51-55.

DePaolo, D.J., 1986. Detailed record of the Neogene Sr isotopic evolution of seawater from DSDP Site 590B. Geology, 14:103-106.

DePaolo, D.J., and Finger, K.L., 1991. High-resolution strontium-isotope stratigraphy and biostratigraphy of the Miocene Monterey Formation, central California. Geol. Soc. Am. Bull., 103:112-124.

DePaolo, D.J., and Ingram, B.L., 1985. High-resolution stratigraphy with strontium isotopes. Science, 227:938-940.

DePaolo, D.J., Kyte, F.T., Marshall, B.D., O'Neil, J.R., and Smit, J., 1983. $\mathrm{Rb}-\mathrm{Sr}, \mathrm{Sm}-\mathrm{Nd}, \mathrm{K}-\mathrm{Ca}, \mathrm{O}$, and $\mathrm{H}$ isotopic study of Cretaceous-Tertiary boundary sediments, Caravaca Spain: evidence for an oceanic impact site. Earth Planet. Sci. Lett., 64:356-373.

Doyle, P.S., and Riedel, W.R., 1979. Cretaceous to Neogene ichthyoliths in a giant piston core from the central North Pacific. Micropaleontology, 25:337-364.

Edgerton, C.C., Doyle, P.S., and Riedel, W.R., 1977. Ichthyolith age determination of otherwise unfossiliferous Deep Sea Drilling Project cores. Micropaleontology, 23:194-205.

Edmond, J.M., Measures, C., McDuff, R.E., Chan, L.H., Collier, R., and Grant, B., 1979. Ridge crest hydrothermal activity and the balances of the major and minor elements in the ocean: the Galapagos data. Earth Planet. Sci. Lett., 46:1-18.

Futa, K., Peterman, Z.E., and Hein, J.R., 1988. Sr and Nd isotopic variations in ferromanganese crusts from the central Pacific: implications for age and source provenance. Geochim. Cosmochim. Acta, 52:2229-2233.

Gottfried, M.D., Doyle, P.S., and Riedel, W.R., 1984a. Advances in ichthyolith stratigraphy of the Pacific Neogene and Oligocene. Micropaleontology, 30:71-85.

1984b. Stratigraphic interpretations of pelagic sequences revised on the basis of ichthyoliths. Micropaleontology, 30:426-444.

Heath, G.R., Rea, D.H., and Levi, S., 1985. Paleomagnetism and accumulation rates of sediments at Sites 576 and 578, Deep Sea Drilling Project Leg 86, western North Pacific. In Heath, G.R., Burckle, L.H., et al., Init. Repts. DSDP, 86: Washington (U.S. Govt. Printing Office), 459-502.

Hess, J., Bender, M.L., and Schilling, J.G., 1986. Evolution of the ratio of strontium-87 to strontium-86 in seawater from Cretaceous to Present. Science, 231:979-984.

Ingram, B.L., 1992. Paleoclimatic and paleoceanographic studies of estuarine and marine sediments using strontium isotopes [Ph.D. thesis]. Stanford Univ., Stanford, CA.

Ingram, B.L., Coccioni, R., Montanari, A., and Richter, F.M., 1994. Strontium isotopic composition of Mid-Cretaceous seawater. Science, 264:546-550.

Ingram, B.L., Hein, J.R., and Farmer, G.L., 1990. Age determinations and growth rates of Pacific ferromanganese deposits using strontium isotopes. Geochim. Cosmochim. Acta, 54:1709-1721.

Janecek, T.R., 1985. Eolian sedimentation in the Northwest Pacific Ocean: a preliminary examination of the data from Deep Sea Drilling Project Sites 576 and 578. In Heath, G.R., Burckle, L.H., et al., Init. Repts. DSDP, 86: Washington (U.S. Govt. Printing Office), 589-603.
Keller, R.A., and the Leg 145 Shipboard Scientific Party, 1993. Age and geochemistry of basaltic basement recovered during ODP Leg 145 (North Pacific Transect). Eos, 74:355.

Kolodny, Y., and Luz, B., 1991. Oxygen isotopes in phosphates of fossil fish: Devonian to Recent. In Taylor, H.P., Jr., O'Neil, J.R., and Kaplan, I.R. (Eds.), Stable Isotope Geochemistry: A Tribute to Samuel Epstein. Geochem. Soc., Spec. Publ. 3:105-119.

Kyte, F.T., Bostwick, J.A., and Zhou, L., 1994. The KT boundary on the Pacific Plate. Proc. Lunar Planet. Sci, 64-65.

Kyte, F.T., Leinen, M., Heath, G.R., and Zhou, L., 1993. Cenozoic sedimentation history of the central North Pacific: inferences from the elemental geochemistry of core LL44-GPC3. Geochim. Cosmochim. Acta, 57:1719-1740.

Kyte, F.T., and Wasson, J.T., 1985. Accretion rate of extraterrestrial matter: iridium deposited 33 to 67 million years ago. Science, 232:1225-1229.

Leinen, M.H., and Heath, G.R., 1981. Sedimentary indicators of atmospheric activity in the Northern Hemisphere during the Cenozoic. Palaeogeogr., Palaeoclimatol., Palaeoecol., 36:1-21.

Mangini, A., Segl, M., Bonani, G., Hofmann, H.J., Morenzoni, E., Nessi, M., Suter, M., Wolfli, W., and Turekian, K.K., 1984. Mass-spectrometric ${ }^{10} \mathrm{Be}$ dating of deep-sea sediments applying the Zurich tandem accelerator. Nucl. Instrum. Methods Phys. Res., Sect. B, 5:353-358.

Palmer, M.R., and Edmond, J.M., 1989. The strontium isotope budget of the modern ocean. Earth Planet. Sci. Lett., 92:11-26.

Rea, D.K., Leinen, M., and Janecek, T.R., 1985. A geological approach to the long-term history of atmospheric circulation. Science, 227:721-725.

Richter, F.M., and DePaolo, D.J., 1987. Numerical models for diagenesis and the Neogene $\mathrm{Sr}$ isotopic evolution of seawater from DSDP Site 590B. Earth Planet. Sci. Lett., 83:27-38.

Richter, F.M., Rowley, D.A., and DePaolo, D.J., 1992. Strontium isotopic evolution of the oceans: the role of tectonics. Earth Planet. Sci. Lett., 109:11-23.

Robin, E., Froget, L., Jehanno, C., and Rocchia, R., 1993. Evidence for a K/T impact event in the Pacific Ocean. Nature, 363:615-617.

Shemesh, A., 1990. Crystallinity and diagenesis of sedimentary apatites. Geochim. Cosmochim. Acta, 54:2433-2438.

Shipboard Scientific Party, 1993. Sites 885/886. In Rea, D.K., Basov, I.A., Janecek, T.R., Palmer-Julson, A., et al., Proc. ODP, Init. Repts., 145: College Station, TX (Ocean Drilling Program), 303-334.

Smit, J., Alvarez, W., Montanari, A., Swinburne, N., Van Kempen, T.M., Klaver, G.T., and Lustenhouwer, W.J., 1992. "Tektites" and microkrystites at the Cretaceous Tertiary boundary: two strewn fields, one crater? Proc. Lunar Planet. Sci. Conf., 22:87-100.

Smit, J., and Romein, A.J.T., 1985. A sequence of events across the Cretaceous-Tertiary boundary. Earth Planet. Sci. Lett., 74:155-170.

Staudigel, H., Doyle, P., and Zindler, A., 1985. Sr and Nd isotope systematics in fish teeth. Earth Planet. Sci. Lett., 76:45-56.

Swinburne, N.H.M., Montanari, A., and DePaolo, D.J., in press. Strontium isotope stratigraphy of the Campanian-Paleocene interval based on pelagic carbonate sequences of the Umbria-Marche Basin (N.E. Apennines, Italy). Geochim. Cosmochim. Acta.

*Abbreviations for names of organizations and publications in ODP reference lists follow the style given in Chemical Abstracts Service Source Index (published by American Chemical Society).

Date of initial receipt: 5 April 1994

Date of acceptance: 1 August 1994

Ms 145SR-130 


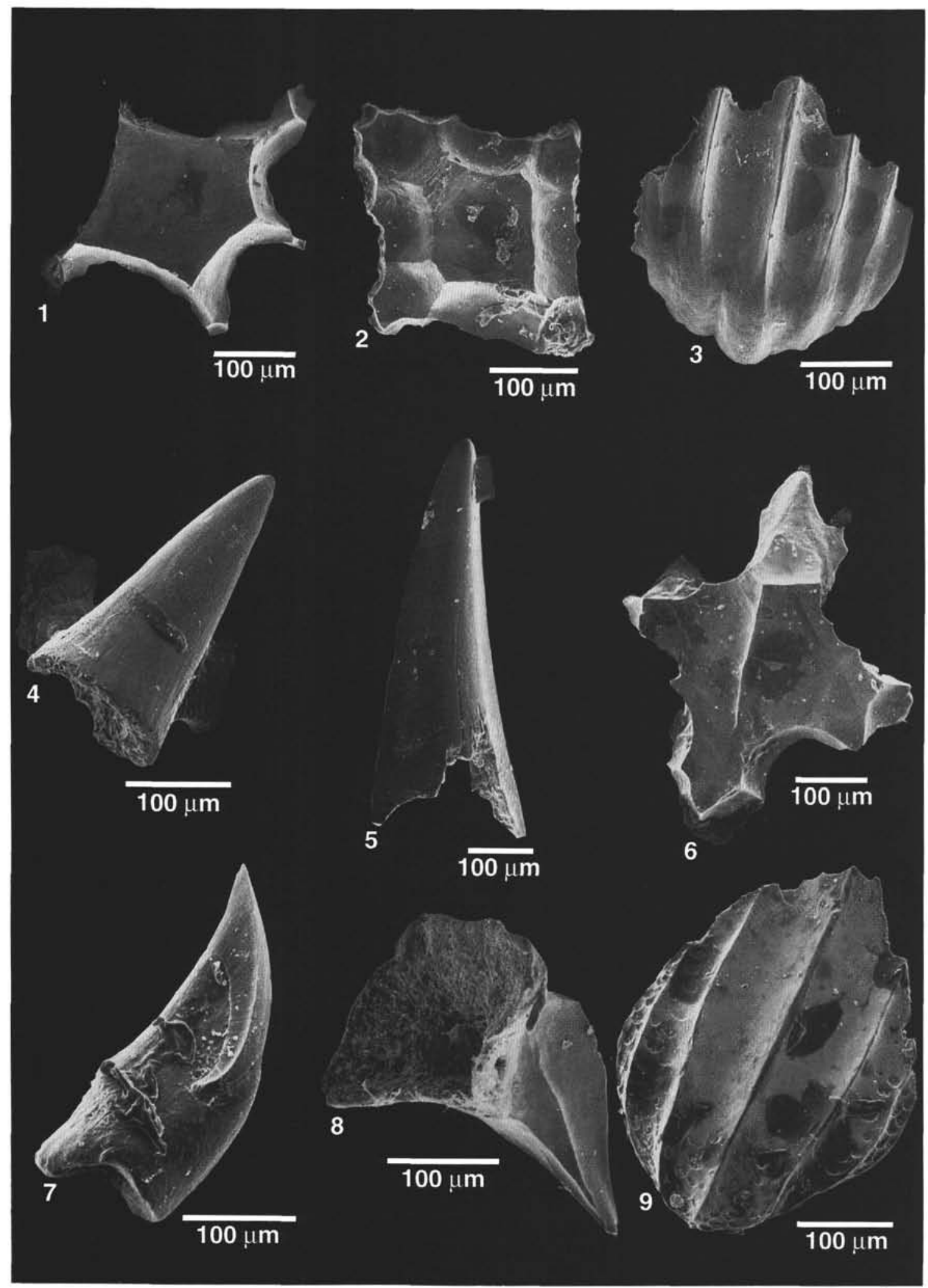

Plate 1. SEM photomicrographs of ichthyoliths. 1. Sample 145-886C-7H-5, 135-140 cm, unidentified ichthyolith. 2. Sample 145-886C-7H-5, 135-140 cm, undescribed by Doyle and Riedel, 1979 (Eocene-Oligocene). 3. Sample 145-886C-7H-5, 135-140 cm, undescribed by Doyle and Riedel, 1979 (Eocene-Oligocene). 4. Sample 145-886C-7H-5, 135-140 cm, Straight flared triangle. 5. Sample 145-886C-7H-5, 135-140 cm, Flexed triangle. 6. Sample 145-886C-8H1, 135-140 cm, Kite shaped elongate prominance. 7. Sample 145-886C-8H-1, 135-140 cm, unidentified. 8. Sample 145-886C-8H-1, 135-140 cm, unidentified. 9. Sample 145-886C-8H-1, 135-140, unidentified. 


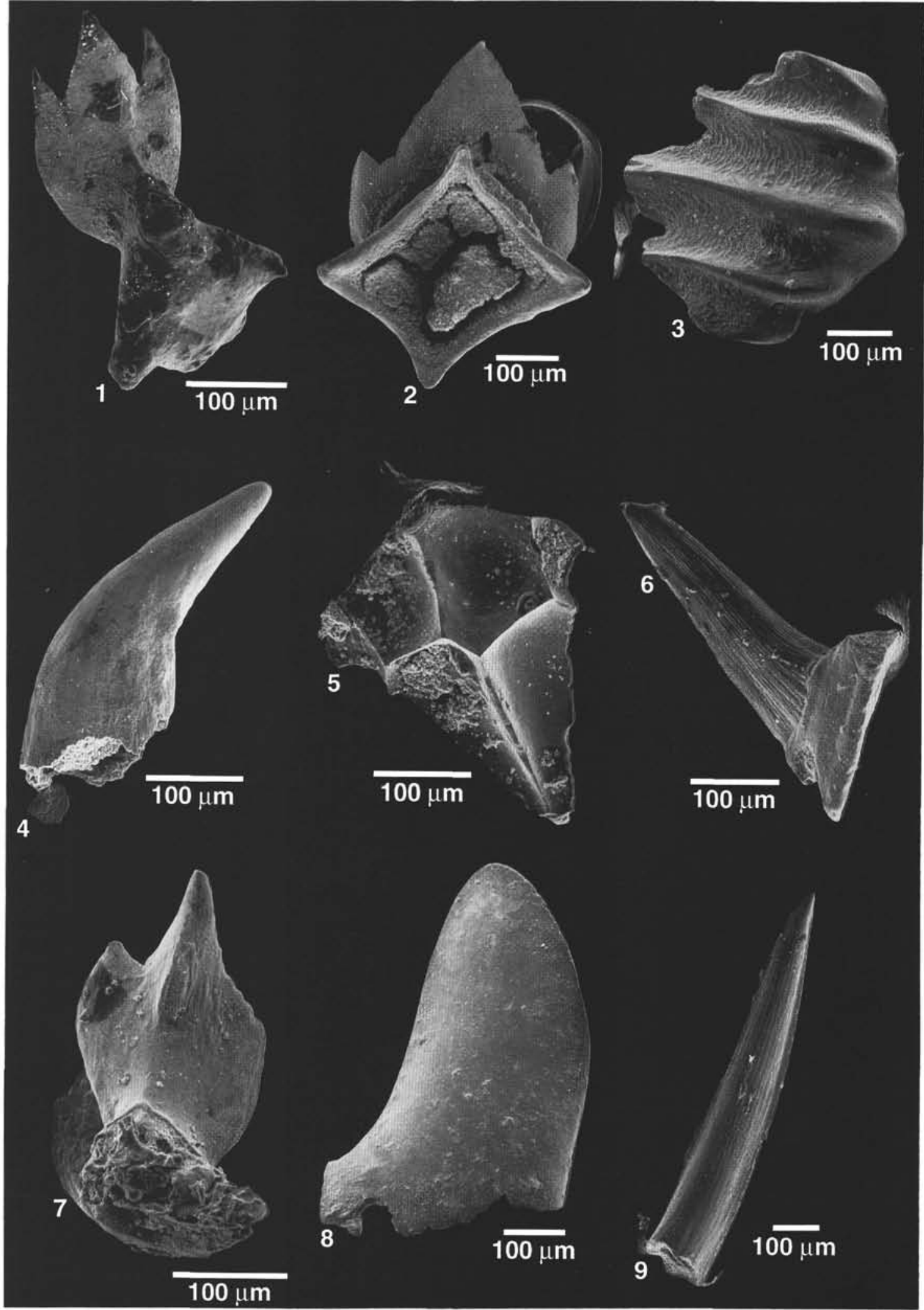

Plate 2. SEM photomicrographs of ichthyoliths. 1. Sample 145-886C-8H-2, 135-140 cm, undescribed form, Doyle and Riedel, 1979. 2. Sample 145-886C-8H2, $135-140 \mathrm{~cm}$, unidentified. 3. Sample 145-886C-8H-2, 135-140 cm, unidentified. 4. Sample 145-886C-8H-2, 135-140 cm, unidentified. 5. Sample $145-$ $886 \mathrm{C}-8 \mathrm{H}-2,135-140 \mathrm{~cm}$, undescribed form, Doyle and Riedel, 1979. 6. Sample 145-886C-8H-2, 135-140 cm, unidentified. 7. Sample 145-886C-8H-3, 135$140 \mathrm{~cm}$, unidentified. 8. Sample 145-886C-8H-3,135-140 cm, undescribed form, Doyle and Riedel, 1979. 9. Sample 145-886C-8H-3, 135-140 cm, unidentified. 


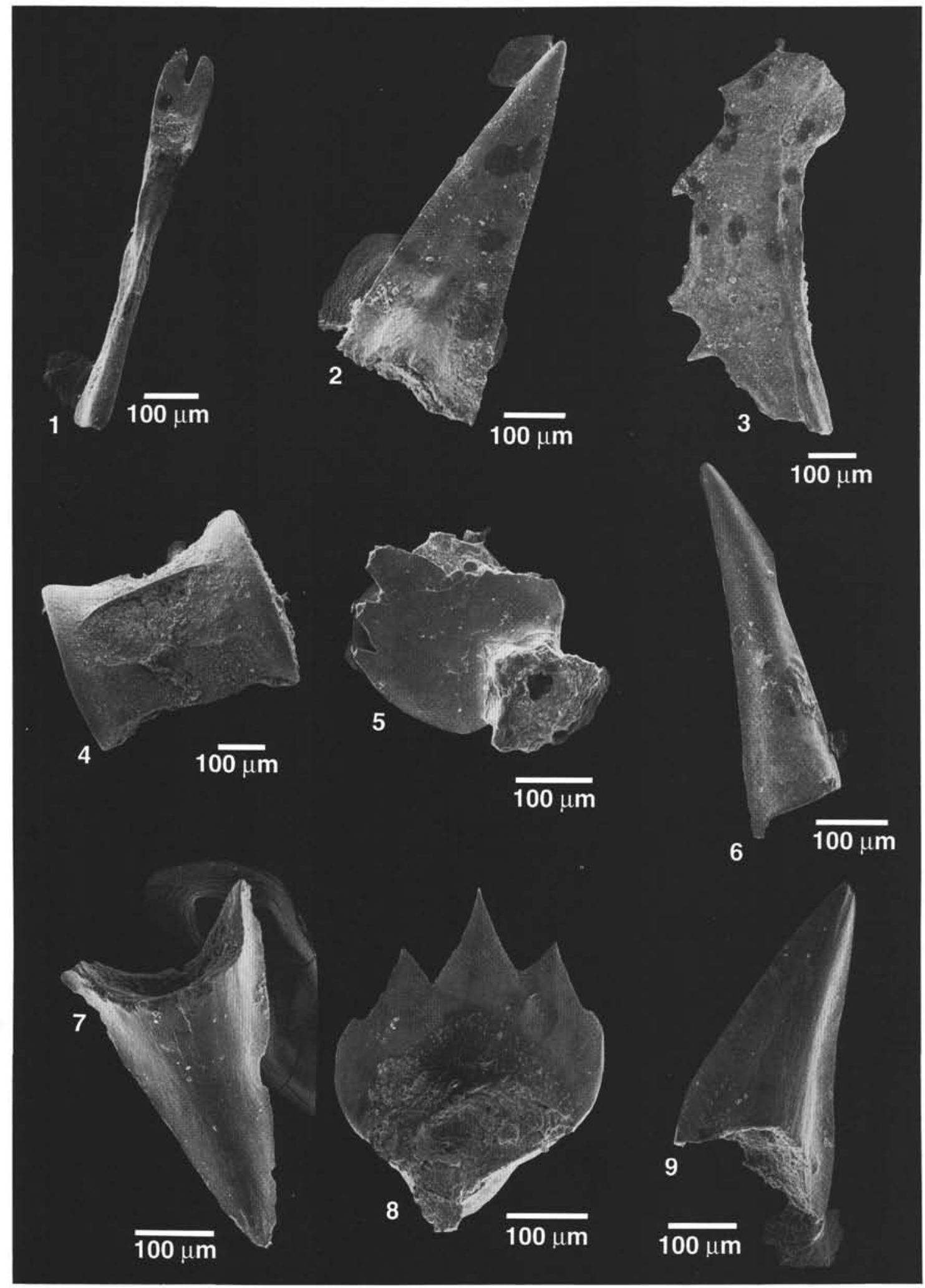

Plate 3. SEM photomicrographs of ichthyoliths. 1. Sample $145-886 \mathrm{C}-8 \mathrm{H}-6,85-90 \mathrm{~cm}$, unidentified. 2. Sample $145-886 \mathrm{C}-8 \mathrm{H}-6$, $85-90 \mathrm{~cm}$, Centrally striated triangle. 3. Sample 145-886C-8H-6, 85-90 cm, unidentified. 4. Sample $145-886 \mathrm{C}-8 \mathrm{H}-6,85-90 \mathrm{~cm}$, unidentified. 5. Sample 145-886C-8H-6, 135-140 cm, unidentified. 6. Sample 145-886C-8H-6, 135-140 cm, unidentified. 7. Sample 145-886C-8H-6, 135-140 cm, unidentified. 8. Sample 145-886C-8H-6, 135-140 $\mathrm{cm}$, undescribed from Doyle and Riedel, 1979. 9. Sample 145-886C-8H-6, 135-140 cm, unidentified. 


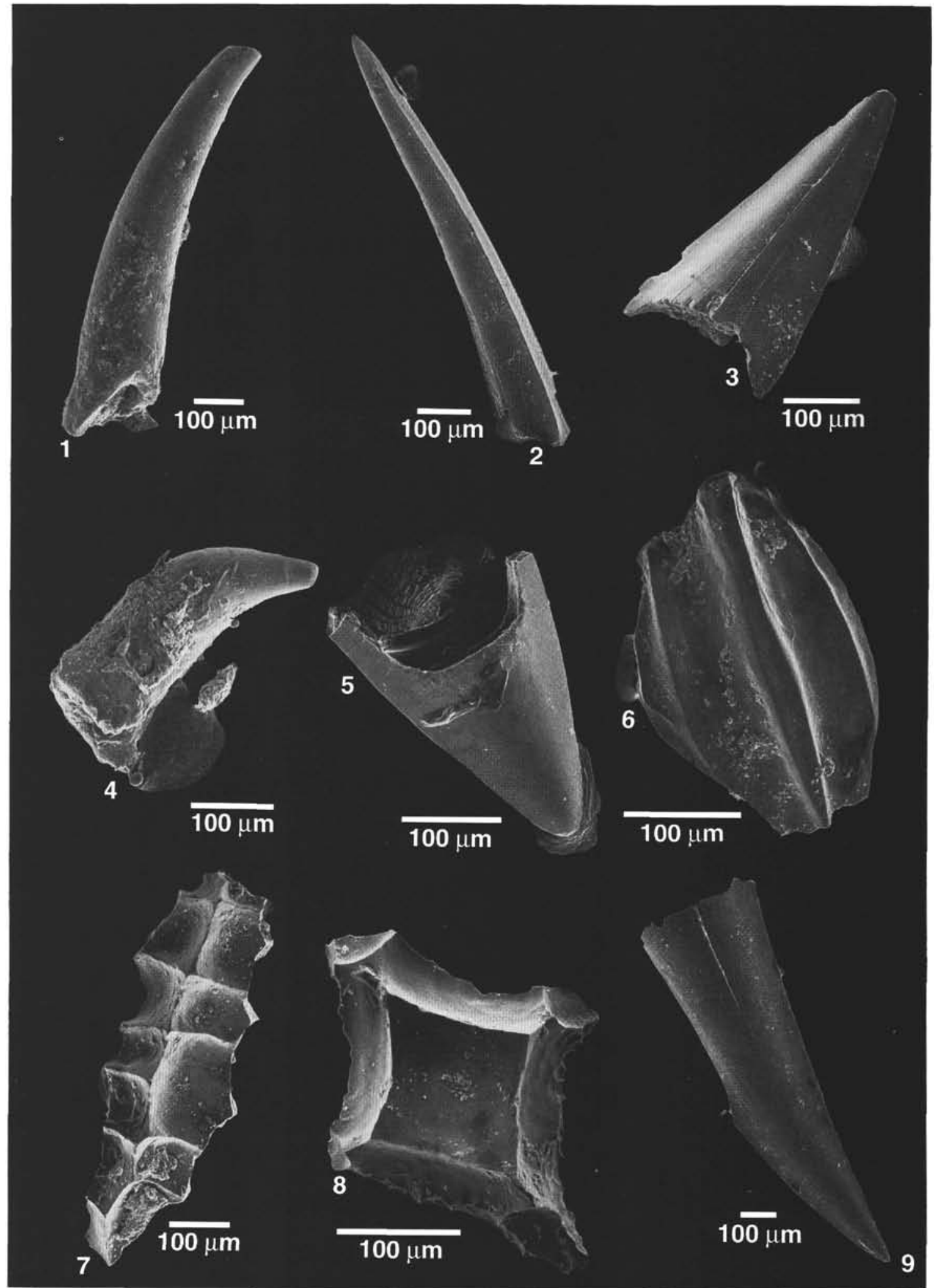

Plate 4. SEM photomicrographs of ichthyoliths. 1. Sample 145-886C-7H-3, 135-140 cm, Narrow triangle short inline. 2. Sample 145-886C-7H-3, 135-140 $\mathrm{cm}$, Narrow triangle ragged base. 3. Sample 145-886C-7H-3, 135-140 cm, unidentified. 4. Sample 145-886C-7H-3, 135-140 cm, unidentified, 5. Sample 145$886 \mathrm{C}-7 \mathrm{H}-4,135-140 \mathrm{~cm}$, Wide triangle straight inbase. 6. Sample 145-886C-7H-4, 135-140 cm, Plain and lined lanceolate. 7. Sample 145-886C-7H-4, 135$140 \mathrm{~cm}$, unidentified. 8. Sample 145-886C-7H-4, 135-140 cm, unidentified. 9. Sample $145-886 \mathrm{C}-7 \mathrm{H}-4,135-140 \mathrm{~cm}$, Triangle medium wing. 

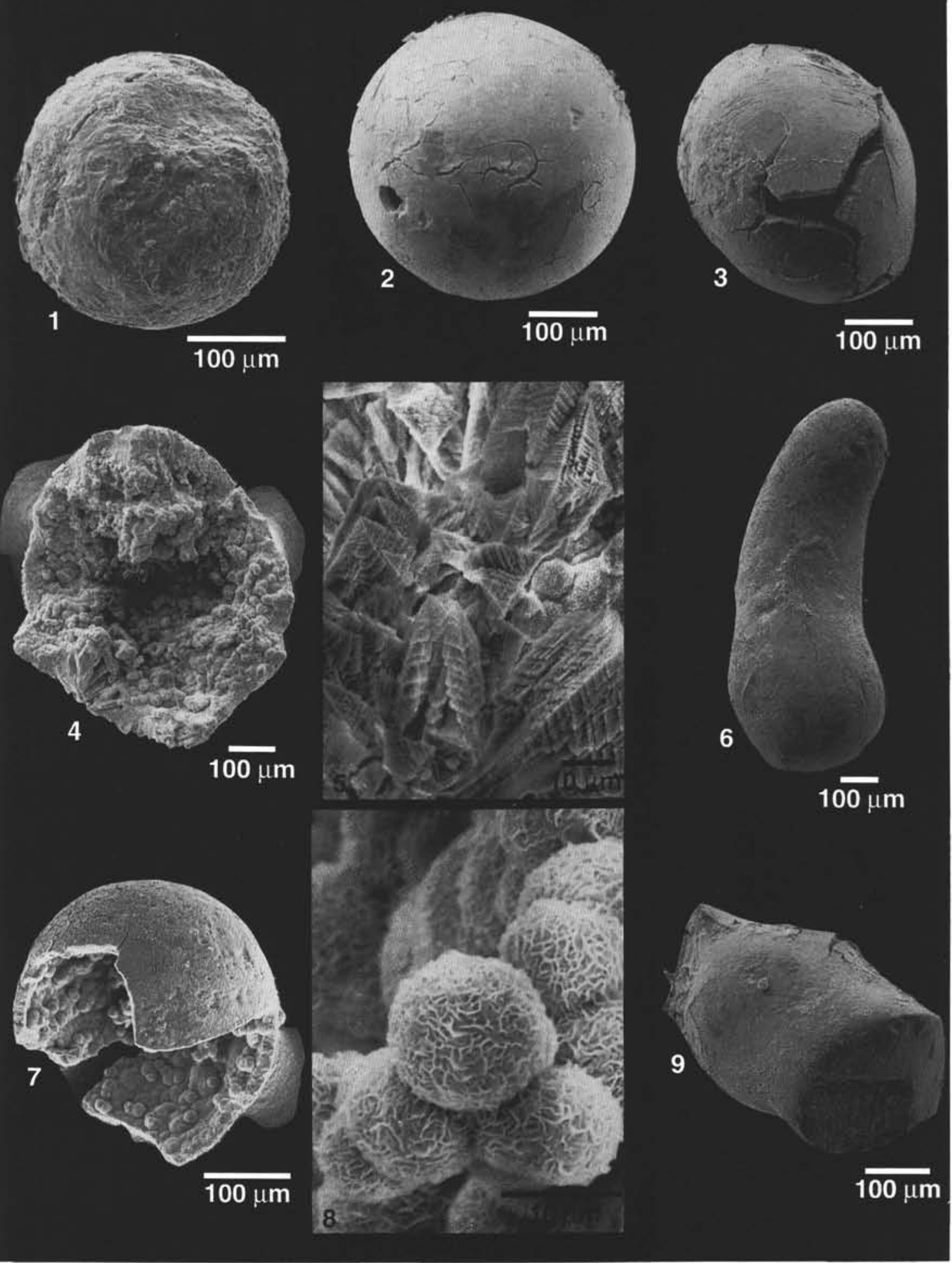

Plate 5. SEM views of spherules. 1. Sample $145-886 \mathrm{C}-8 \mathrm{H}-1,135-140 \mathrm{~cm}$, smaller diameter spherule $(150 \mu \mathrm{m})$ with rough outer surface. 2. Sample 145-886C$8 \mathrm{H}-1,135-140 \mathrm{~cm}$, larger diameter spherule $(500 \mu \mathrm{m})$ with smooth outer surface. 3. Sample $145-886 \mathrm{C}-8 \mathrm{H}-1,135-140 \mathrm{~cm}$, deformed spherule with hollow interior. 4. Sample 145-886C-8H-1, 135-140 cm, broken spherule, filled with authigenic minerals. 5. Sample 145-886C-8H-1, 135-140 cm, high magnification of (4), showing dendritic or feathery habit of smectite clays. 6. Sample $145-886 \mathrm{C}-8 \mathrm{H}-1,135-140 \mathrm{~cm}$, elongated "dumbbell"-shaped spherule. 7. Sample 145$886 \mathrm{C}-8 \mathrm{H}-1,135-140 \mathrm{~cm}$, broken spherule, with dessication cracks on surface and lined with smectite. 8. Sample $145-886 \mathrm{C}-8 \mathrm{H}-1,135-140 \mathrm{~cm}$, smectite spheroid at higher magnification, showing crenulated (webby) surface texture. 9. Sample $145-886 \mathrm{C}-8 \mathrm{H}-1,135-140 \mathrm{~cm}$, irregular shaped spherule. 


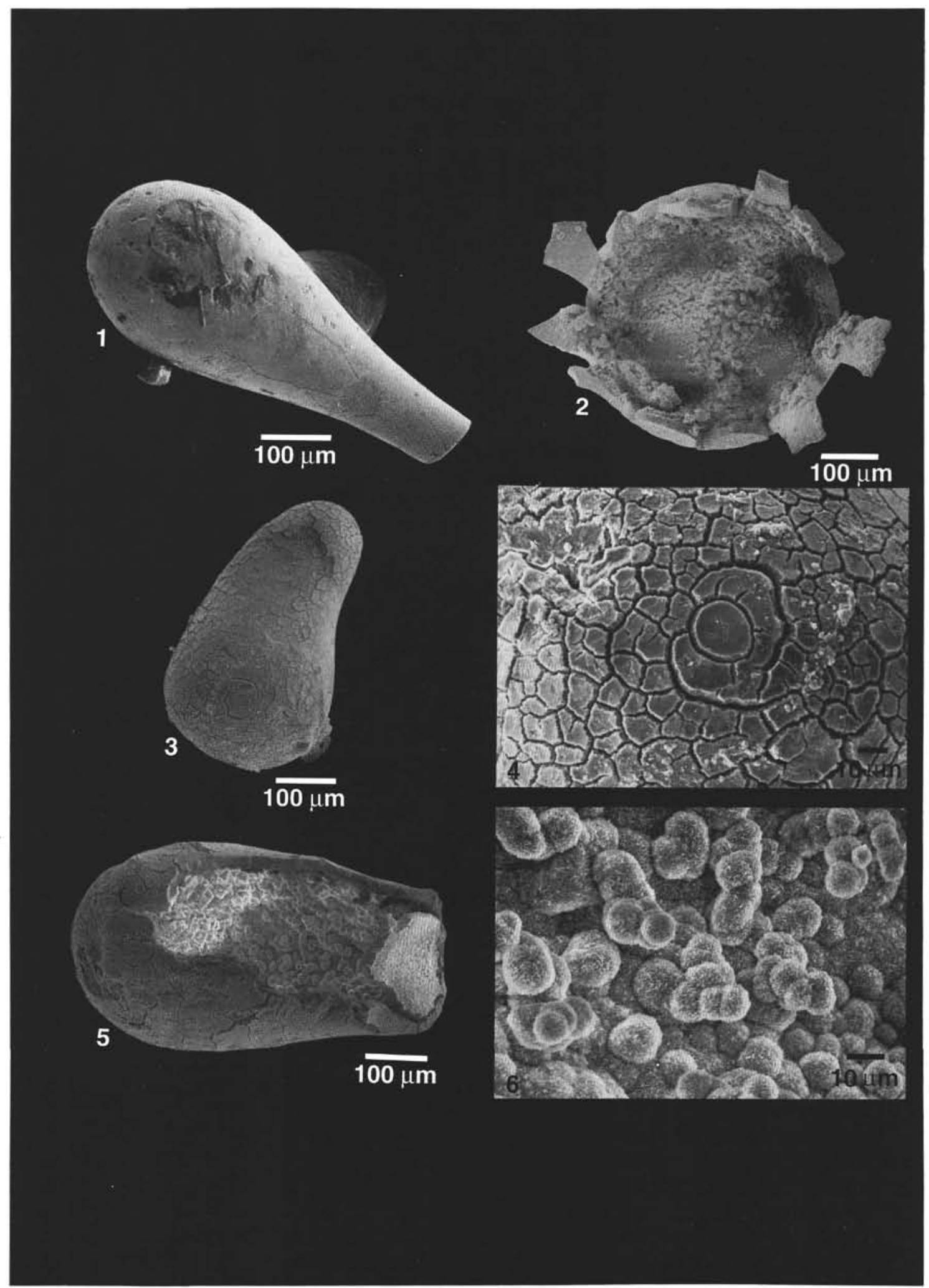

Plate 6. SEM views of spherules. 1. Sample $145-886 \mathrm{C}-8 \mathrm{H}-1,135-140 \mathrm{~cm}$, teardrop-shaped spherule, about $600 \mu \mathrm{m}$ across 2 . Sample 145-886C-8H-1, 135-140 $\mathrm{cm}$, broken spherule, filled with smectite. 3. Sample 145-886C-8H-1, 135-140 cm, dumbbell-shaped spherule, with dessication cracks on outer surface. 4. Sample 145-886C-8H-1, 135-140 cm, higher magnification of dessication cracks. 5. Sample 145-886C-8H-1, 135-140 cm, broken dumbbell-shaped spherule, filled with smectite. 6. Sample 145-886C-8H-1, 135-140 cm, higher magnification of smectite, showing crenulated, or webby, surface texture. 